\title{
Splice-mediated Variants of Proteins (SpliVaP) - data and characterization of changes in signatures among protein isoforms due to alternative splicing Matteo Floris ${ }^{\dagger}$, Massimiliano Orsini ${ }^{\dagger}$ and Thangavel Alphonse Thanaraj*
}

\author{
Address: CRS4-Bioinformatica, Parco Scientifico e Technologico, POLARIS, Edificio 3, 09010 PULA (CA), Sardinia, Italy \\ Email: Matteo Floris - floris@crs4.it; Massimiliano Orsini - orsini@crs4.it; Thangavel Alphonse Thanaraj* - thanaraj@crs4.it \\ * Corresponding author †Equal contributors
}

Published: 2 October 2008

BMC Genomics 2008, 9:453 doi:10.1186/147|-2164-9-453

This article is available from: http://www.biomedcentral.com//47I-2/64/9/453

(C) 2008 Floris et al; licensee BioMed Central Ltd.

This is an Open Access article distributed under the terms of the Creative Commons Attribution License (http://creativecommons.org/licenses/by/2.0), which permits unrestricted use, distribution, and reproduction in any medium, provided the original work is properly cited.

\begin{abstract}
Background: It is often the case that mammalian genes are alternatively spliced; the resulting alternate transcripts often encode protein isoforms that differ in amino acid sequences. Changes among the protein isoforms can alter the cellular properties of proteins. The effect can range from a subtle modulation to a complete loss of function.

Results: (i) We examined human splice-mediated protein isoforms (as extracted from a manually curated data set, and from a computationally predicted data set) for differences in the annotation for protein signatures (Pfam domains and PRINTS fingerprints) and we characterized the differences \& their effects on protein functionalities. An important question addressed relates to the extent of protein isoforms that may lack any known function in the cell. (ii) We present a database that reports differences in protein signatures among human splice-mediated protein isoform sequences.

Conclusion: (i) Characterization: The work points to distinct sets of alternatively spliced genes with varying degrees of annotation for the splice-mediated protein isoforms. Protein molecular functions seen to be often affected are those that relate to: binding, catalytic, transcription regulation, structural molecule, transporter, motor, and antioxidant; and the processes that are often affected are nucleic acid binding, signal transduction, and protein-protein interactions. Signatures are often included/excluded and truncated in length among protein isoforms; truncation is seen as the predominant type of change. Analysis points to the following novel aspects: (a) Analysis using data from the manually curated Vega indicates that one in 8.9 genes can lead to a protein isoform of no "known" function; and one in 18 expressed protein isoforms can be such an "orphan" isoform; the corresponding numbers as seen with computationally predicted ASD data set are: one in 4.9 genes and one in 9.8 isoforms. (b) When swapping of signatures occurs, it is often between those of same functional classifications. (c) Pfam domains can occur in varying lengths, and PRINTS fingerprints can occur with varying number of constituent motifs among isoforms since such a variation is seen in large number of genes, it could be a general mechanism to modulate protein function. (ii) Data: The reported resource (at http://www.bioinformatica.crs4.org/tools/dbs/ splivap/) provides the community ability to access data on splice-mediated protein isoforms (with valueadded annotation such as association with diseases) through changes in protein signatures.
\end{abstract}




\section{Background}

Human genome encodes a surprisingly low number of genes; however a large transcriptome has been reported for human [1-3]. Alternative splicing of exons, during the processing of pre-mRNA, is a major contributor to the diversity seen in transcriptome and proteome [4,5]. Transcript isoforms from a gene often encode functionally diverse protein isoforms [5-9]. It has been reported that gene regulation through alternative splicing is more versatile than that through promoter activity $[1,10]$. The many other mechanisms that the cell uses to introduce variation at gene or transcript or protein level (such as RNA editing and post-translational modifications) are themselves affected by alternative splicing (for example, introduction of protein domains that bring about post-translational modifications [5]).

Alternative splicing leads to variants of proteins with diverse changes that can range from profound effects to fine modulation of protein activity [11]. An example that illustrates drastic change can be seen among the isoforms of caspase- 9 protease: the constitutive form of the protein induces apoptosis, while its shorter isoform acts as an inhibitor [12]. An example that illustrates fine modulation can be seen among the isoforms of AT1: the protein product of human AT1 (angiotensin II type 1 receptor) gene binds to angiogenesis II (Ang II) hormone peptide; four transcript isoforms have been identified for hAT1 gene that essentially leads to two protein isoforms differing from one another by a 32-amino acid extension at the $\mathrm{N}$-terminal; the shorter isoform has higher affinity to the hormone peptide than the longer isoform; the potency of the Ang II response varies depending on the relative abundance of these two protein isoforms [13].

Splice-mediated changes at transcript level can be seen in both the untranslated and the coding regions. Changes in the untranslated regions can lead to inclusion/exclusion/ modification of RNA regulatory elements responsible for the translatability of the mRNA. Changes in coding regions can lead to insertion/deletion/substitution of amino acid residues in the encoded proteins and thereby bring about differences in the constituent functional/ structural motifs; such changes in a protein can alter its binding properties (e.g. in terms of the binding affinities and the types of binding molecules), can influence its intracellular localization $(e . g$. in terms of effecting changes on signal peptides or localization signals), can modify its enzymatic activity (e.g. in terms of effecting changes in substrate specificity, catalytic properties or affinity), and can modify its intrinsic stability (e.g. by introducing regions for autophosphorylation or signals for cleavage) $[5,14]$. The effects due to such changes can range from a complete loss of function to very subtle activity modulation. The 3-dimensional structure of a protein can be dras- tically altered by splice-mediated deletion of large regions or even of small regions that are part of long-range structural stabilizations; modeling studies $[1,6]$ have reported that up to $67 \%$ of alternative spliced isoforms can show significant alterations in regions that form the core of protein structure and thereby large conformational differences. Tress et al [15] find little evidence as to whether a majority of protein isoforms have a role as functional proteins.

Missplicing events can cause or contribute to human diseases. At least $15 \%$ of human disease-causing mutations occur at splice sites [16]; mutations and genetic variations can alter the splice site signals and splice regulatory elements to mediate formation of alternate transcripts and protein isoforms [17-20]. Aberrantly spliced isoforms play a direct role in transformation, motility and metastasis of tumor tissue; array and RT-PCR experiments [21] confirm that differentially expressed transcripts correlate extremely well with known cancer genes and pathways; and cancer-specific novel splice isoforms have been identified in human expressed sequence collections [22]. It is important to characterize functional changes in protein isoforms and to understand the association between the pathological states of the cell and the synthesized protein isoforms; this will help in developing novel peptide-based probes and targets for identifying and treating human diseases.

We considered two large data sets of splice-mediated protein isoform sequences from human and delineated differences in signatures among the isoforms - the data sets of examined protein isoforms are of two different types, namely one from a database of manually curated isoforms and the other from computationally predicted splice isoforms as seen in EST resources. Changes among protein isoform sequences are discussed in terms of inclusion/ exclusion/alternation/truncation of protein signatures (domains as defined by Pfam [23] and fingerprints (as defined by PRINTS [24]) as well as in terms of lack of annotation for signatures. We present to the community the resultant database (SpliVaP) containing information on changes in the composition and structure of signatures among protein isoform sequences (with value-added annotations such as associations with diseases).

\section{Methods}

\section{Data on protein isoform sequences}

For data on protein isoform sequences, we considered two independent sources - one based on manually curated database of splice isoforms, and another based on computational delineation of splice isoforms from EST sequences. 


\section{Manually curated data set}

For curated data on splice-mediated protein isoforms, we used Vega (The vertebrate genome annotation) database [25] as available from http://vega.sanger.ac.uk/ Homo sapiens/index.html. Vega acts as the central repository for the majority of genome sequencing centres to deposit their annotation of human chromosomes. The manual curation of the human genome in Vega is thus performed by an international group of collaborators (see http://vega.sanger.ac.uk/info/about/

man annotation.html for details). We used release v31 (Apr 2008) of the Vega database for homo sapiens for the current study. The data set was cleaned for redundant protein isoform sequences - if two or more protein isoform sequences from a gene are identical to one another, only one was retained. The such cleaned data set comprises 33502 protein isoforms from 9649 human genes.

\section{Computationally predicted data set}

We extracted data on splice-mediated protein isoforms from Alternative Splicing Database (ASD) [26] as available from http://www.ebi.ac.uk/asd. Release 3 [27] of the ASD database for homo sapiens was used for the current study; the data set was cleaned for redundant protein isoform sequences - if two or more protein isoform sequences from a gene are identical to one another, only one was retained. The such cleaned data set comprises 27,241 protein isoforms from 7,664 human genes. A brief note on the derivation of data on protein isoform sequences by the ASD pipeline is in order here. ASD pipeline uses EST/mRNA transcript sequence data to firstly identify isoform splice patterns of a gene; nucleotide sequence of an isoform splice pattern is derived by extracting the appropriate exon regions from the gene sequence; the relevant protein sequence corresponding to such a splice pattern is then derived from the nucleotide sequence of the splice pattern by adopting one of the following two approaches: (a) mRNA evidence: When one of the transcript sequences confirming the splice pattern is an mRNA with annotation for coding information (i.e. start and end of translated region), the information is used to translate the splice pattern sequence onto protein sequence; such a derived protein sequence is annotated as having mRNA experimental evidence; it is often the case that such annotated mRNA entries are associated with protein sequence entries in UniProt [28] database. (b) ASD prediction: This is for those splice patterns that are confirmed entirely by EST sequences or by mRNA with no annotation for coding information. All regions starting with ATG codon from the splice pattern sequence are assessed for translatability; length of the translated peptide and the overall match to a reference protein are assessed. Thresholds based on ATG-context scores [29] (as detected using a set of experimentally determined translation initiation codons on human mRNAs) are applied.
Longest open reading frame is then selected to give rise to translated protein sequence.

\section{Annotation of protein isoform sequences for PRINTS fingerprints and Pfam domains \\ Annotation for PRINTS fingerprints}

A PRINTS fingerprint [24] is a group of conserved motifs used to characterize a protein family. The fingerprint concept is based on the fact that sequences of proteins from a family hold in common subsequences (sequence motifs) that usually relate to key functional elements or core structural elements; the motif is any conserved element seen in the alignment of sequences forming a family. InterProScan [30] is a tool that identifies fingerprints in a given protein sequence. Annotation by InterProScan for a fingerprint does not necessarily mean that all the constituent motifs of the fingerprint are seen in a given protein sequence. We aligned the protein isoform sequences from our data sets with PRINTS fingerprint signatures using InterProScan. We retained only those alignments with an E-value $\leq 10^{-5}$. Annotation for fingerprints can produce partial or total overlap in fingerprint definitions along the length of the sequences; such isoforms numbered 2257 in the case of Vega and 711 in the case of ASD.

\section{Annotation for Pfam domains}

Pfam is a large collection of multiple sequence alignments and hidden Markov models covering many common protein domains and families. Alignments of the protein isoforms with Pfam definitions were performed by using HmmPfam [31,32]. We retained only those annotations with an E-value $\leq 10^{-5}$. Annotation of protein sequences for Pfam domains can produce partial or total overlap in domain definitions along the length of the sequences; such isoforms numbered only 173 in Vega data set, and 405 in ASD data set.

\section{Examining the protein isoforms for changes in signatures (fingerprints or domains)}

For every gene, we firstly identified a reference protein which is the longest of the expressed protein isoforms; choosing the longest protein as reference is justified by an observation that in only $<5 \%$ instances of genes, the longest peptide had fewer Pfam domains or PRINTS signatures than the other isoforms. We then identified changes in signatures as seen between such a reference protein and each of the protein isoforms. Definitions of such splicemediated changes are illustrated in Figure 1. Splice-mediated changes in an isoform is identified by firstly performing a dynamic alignment of the signature pattern of the isoform with that of the reference protein. Three types of alignments can result - (i) Same Patterns: the composition and order of the signatures are same in both the reference and isoform protein; however, this set of isoforms can still contain truncation events (change in length of a 


\section{Definition of events with PRINTS fingerprints}

Insertion/deletion of fingerprints:

Class A: A 'complete' fingerprint seen with all constituent motifs in an
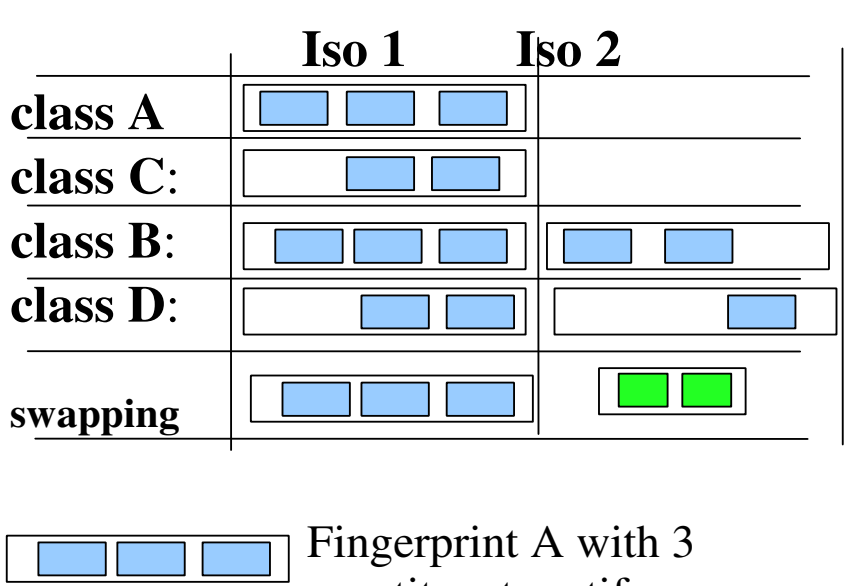

Fingerprint A with 3

constituent motifs.

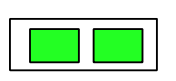

Fingerprint B with 2

constituent motifs. isoform is not present in the other isoform.

Class C: A 'partial' fingerprint seen with only some of the constituent motifs is not present in the other isoform.

\section{Truncation of fingerprints}

(Insertion/deletion of some of the constituent motifs of

fingerprints):

Class B: A fingerprint seen in an isoform as 'complete' (with all its constituent motifs) is present in the other isoform as 'partial' with less motifs.

Class D: A fingerprint is seen in both the isoforms as 'partial' but in one isoform, the fingerprint is seen with more of the constituent motifs.

\section{Swapping of fingerprints:}

A fingerprint seen (as complete or partial) in an isoform is swapped with another in the other isoform.

\section{Definition of events with Pfam domains}

\section{Insertion/deletion of domains}

\author{
Truncation \\ of domains
} Swapping
of domains
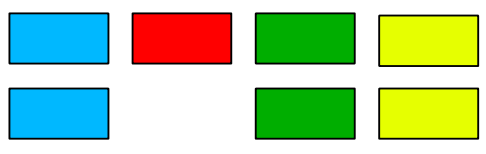

Truncation
of domains
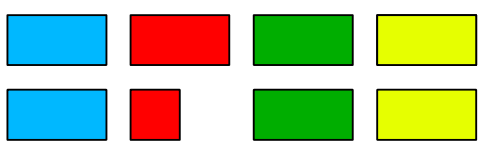

An insertion/deletion event indicates that : domain seen in an isoform is not present in the other isoform.

A truncation event indicates that a domain undergoes change in length between two isoforms.

A swap event indicates that a domain alternates with another between isoforms.

\section{Reshuffling of domains}
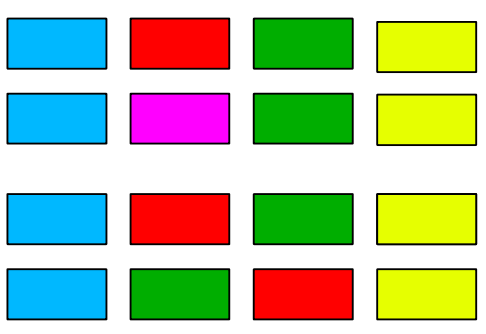

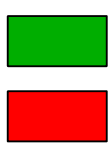

A reshuffle event indicates a change in the positional order of domains.

Figure I

Definitions of splice-mediated changes in the annotation for PRINTS fingerprints and Pfam domains among protein isoforms. 
Pfam domain or change in the number of constituent motifs of a fingerprint at an aligned position). (ii) Totally Different Patterns: none of the signatures seen in the reference protein is present in the isoform; and (iii) Patterns with Changes: there are changes in the composition and order of signatures between the reference and isoform protein; however, at least one common signature could be seen. The cases of Totally Different Patterns were not taken up for further analysis because they can be results of the artifacts in peptide delineations or results of strict criteria used to annotate for signatures. The other two types are taken up for further characterization as below: (i) The Patterns with Changes are examined further for specific types of changes (such as insertion/deletion, truncation, swap, and reshuffle) by scrutinizing the aligned positions; and (ii) the Same Patterns are examined further for truncation event. In our alignment schema, a position is occupied either by a signature or by a gap; the signature is characterized by the name, number of constituent motifs (in the case of fingerprints) or by the length in amino acids residues (in the case of domains).

\section{Insertion/Deletion and Truncation of PRINTS fingerprints}

A PRINTS fingerprint is defined by a collection of constituent motifs. A variety of changes in fingerprint patterns can be seen among protein isoforms - none or only few or all of the constituent motifs of a fingerprint predicted in an isoform can be seen in the other isoforms. We categorized insertion/deletion changes seen between two isoform sequences onto 4 classes as defined below: Class A event: A 'complete' fingerprint seen (with all its constituent motifs) in an isoform is totally lost in the other isoform; Class B event: A 'complete' fingerprint (with all its constituent motifs) is seen in an isoform while some of its constituent motifs are lost in the other isoform; Class $\mathrm{C}$ event: A 'partial' fingerprint seen (with only some of the constituent motifs) in an isoform is not seen in the other isoform; Class D event: Both the isoforms possess the fingerprint as 'partial', but one isoform shows more of the constituent motifs. We term the Class $\mathrm{A}$ and $\mathrm{C}$ events as Insertion/Deletion of fingerprints, and Class $\mathrm{B}$ and $\mathrm{D}$ events as Truncation of fingerprints.

\section{Insertion/deletion of Pfam domains}

A gap in the aligned position leads to identification of domain insertion/deletion. We observe in our data sets that a considerable number of protein isoforms are annotated with successive repeats of a domain. Such repeats can be collectively considered as one entity of domain; in instances of insertion/deletions of some of the repeats but not all, we annotate the change as Insertion/Deletion Reduction of repeats; and when all the repeats are involved, we annotate the change as Insertion/Deletion All repeats. We find that delineation of events is ambiguous when a protein isoform is annotated with repeats of domains, and we tend to ignore such instances for identifying events.

\section{Truncation of Pfam domains}

Pfam domains are derived from alignments of a representative set of sequences. For each domain are available manually verified multiple alignments, hidden Markov Models (HMM) and full-alignments. A single protein can belong to several Pfam families. For each database search, sequences that score more than the family-specific threshold are aligned to the HMM profile automatically to make a full alignment. Thus domains can have more than one defined region that can differ in length across taxonomy; it is often the case that a domain can have a large defined region of sequence on eukaryotic proteins as compared to their homologs in prokaryotes. We examined the lengths of every domain from aligned positions; and the domain is considered to undergo truncation when the lengths differ by more than 5 amino acid residues at an aligned position.

\section{Swapping of signatures among protein isoforms}

A swap event is indicated by two gaps at successive aligned positions (one from each of the aligned reference and isoform protein sequence). A note on swap events with PRINTS fingerprints: A fingerprint seen (either as 'complete' or 'partial') in reference protein is swapped with another fingerprint ('complete' or 'partial') in the isoform sequence.

\section{Reshuffling of signatures among protein isoforms}

A reshuffle event is identified when the order of occurrence of 2 or more signatures as seen in the reference protein is reversed in the isoform sequence.

\section{Quality check on the detection of events}

The alignments of the signature patterns were manually curated. Detected events from the alignments were double-checked for correctness by developing scripts that implement heuristics-based methods.

\section{Associations of isoforms with structural data}

In order to provide to community structural data corresponding to protein isoforms, we performed BLAST [33] alignments of the protein isoform sequences with the sequences of structural entries in the Macromolecular Structure Database (MSD) [34]. Structural data for a protein isoform sequence from our data set is considered to be present in MSD, if the coverage $\geq 98.0 \%$ (i.e. at least $98 \%$ of the residues from the query sequence aligns with the target sequence in MSD with no gaps) and the identity is $\geq 98.0 \%$ (i.e. at least $98 \%$ of aligned positions are occupied by same amino acid residue in both the query and target sequences). For such isoform sequences, we made associations with MSD entries in our database. 


\section{Association with genetic disorders}

Information on gene associations with diseases was obtained from the resource of Online Mendelian Inheritance in Man (OMIM) [35]. For each of the genes thus associated, we extracted the PubMed Identifiers of the journal articles cited in the OMIM entry. We then extracted all the Mesh terms associated with these PubMed Identifiers. These mesh terms and the OMIM terms were attributed as keywords describing the association of genes to diseases.

\section{Examination of transcript isoforms (encoding the protein isoforms) for susceptibility to nonsense-mediated decay (NMD)}

This was done for splice isoforms from the ASD data set. Splice patterns corresponding to the protein isoforms were extracted from the ASD database. If the position of stop codon is seen mapped more than 50 nucleotides upstream of the last exon-exon junction of the splice pattern, then such a splice pattern is considered as a possible target for nonsense-mediated decay [36-38].

\section{Discussion \\ Varying degrees of annotation of protein isoforms for Pfam/PRINTS signatures}

We considered two data sets (one from Vega and the other from ASD) of human genes with at least two or more protein isoform sequences identified for each gene; the protein isoform sequences were then examined for the presence of Pfam/PRINTS signatures. This exercise resulted in four distinct data sets (See Figure 2 for flow of data across different steps leading to the following distinct data sets):

Set A (with Vega: 2106 genes; 0 annotated isoforms; 6668 unannotated isoforms from all the 2106 genes; with ASD: 3934 genes; 0 annotated isoforms; 12741 unannotated isoforms from all the 3934 genes): This set contains those genes for which none of the reported protein isoforms could be annotated for Pfam/PRINTS signatures. The reasons for lack of annotation may include (i) that the criteria on thresholds used in the methodologies to review the alignments of Pfam and fingerprints with the protein isoform sequences is strict; and (ii) that examining the sequences only for Pfam domains and PRINTS fingerprints is not enough and further resources may need to be used.

Set B (with Vega: 1128 genes; 1128 annotated isoforms from all the 1128 genes; 1826 unannotated isoforms from all the 1128 genes; with ASD: 382 genes; 382 annotated isoforms from all the 382 genes; 693 unannotated isoforms from all the 382 genes): This set contains those genes for which only one of the protein isoform sequences could be annotated and the other isoforms lack annotation. It is possible to say that the only annotated isoform represents the constitutively expressed protein product and that any of its variants lack functions (within the constraints highlighted above for Set A).

Set C (with Vega: 1742 genes; 4340 annotated isoforms from all the 1742 genes; 1243 unannotated isoforms from 590 genes; with ASD: 670 genes; 1730 annotated isoforms from all the 670 genes; 691 unannotated isoforms from 359 genes): This set contains those genes for which two or more protein isoform sequences could be annotated but no decipherable changes could be observed in the annotation for signatures between the reference protein and any of the isoforms. Though the annotated isoforms are different from one another in amino acid sequence, they do not exhibit any change in signatures - the possible reasons are that (i) the amino acid differences are small and do not affect the domain/fingerprint definitions; and (ii) the regions that are different among the isoforms are not annotated for domains/fingerprints and hence no change in signatures is seen among the isoforms.

Set D (with Vega: 4673 genes; 15610 annotated isoforms from all the 4673 genes; 2687 unannotated isoforms from 1385 genes; with ASD: 2678 genes; 8376 annotated isoforms from all the 2678 genes; 2628 unannotated isoforms from 1346 genes): This set contains those genes for which two or more protein isoform sequences could be annotated and changes in signatures could be seen between the annotated reference and at least one of the isoforms. Some of the isoforms of a subset of genes lack annotation.

The observed varying degree of annotation indicate lack of signatures in all or some of the protein products from certain genes; such a lack of annotation has been observed by other researchers as well - e.g. based on the work using full-length human cDNAs from $\mathrm{H}$-invitational transcriptome data, Takeda et al [39] find that in $20 \%$ instances of alternatively spliced human genes, the protein products lacked annotation for protein motifs. For the work undertaken in this study (splice-mediated changes in protein isoforms), Set D is the appropriate resource as it presents a list of genes in which two or more protein isoforms could be annotated for Pfam/PRINTS signatures and changes in signatures could be deciphered among the protein isoforms. In all the subsequent discussions, the Set D is used.

\section{Splice-mediated events with PRINTS fingerprints among protein isoforms Overlapping annotation for fingerprints and the effects that alternative splicing has \\ We found 610 peptides in Set $\mathrm{D}$ of the Vega data set to be annotated in an overlapping manner, 513 of which have}




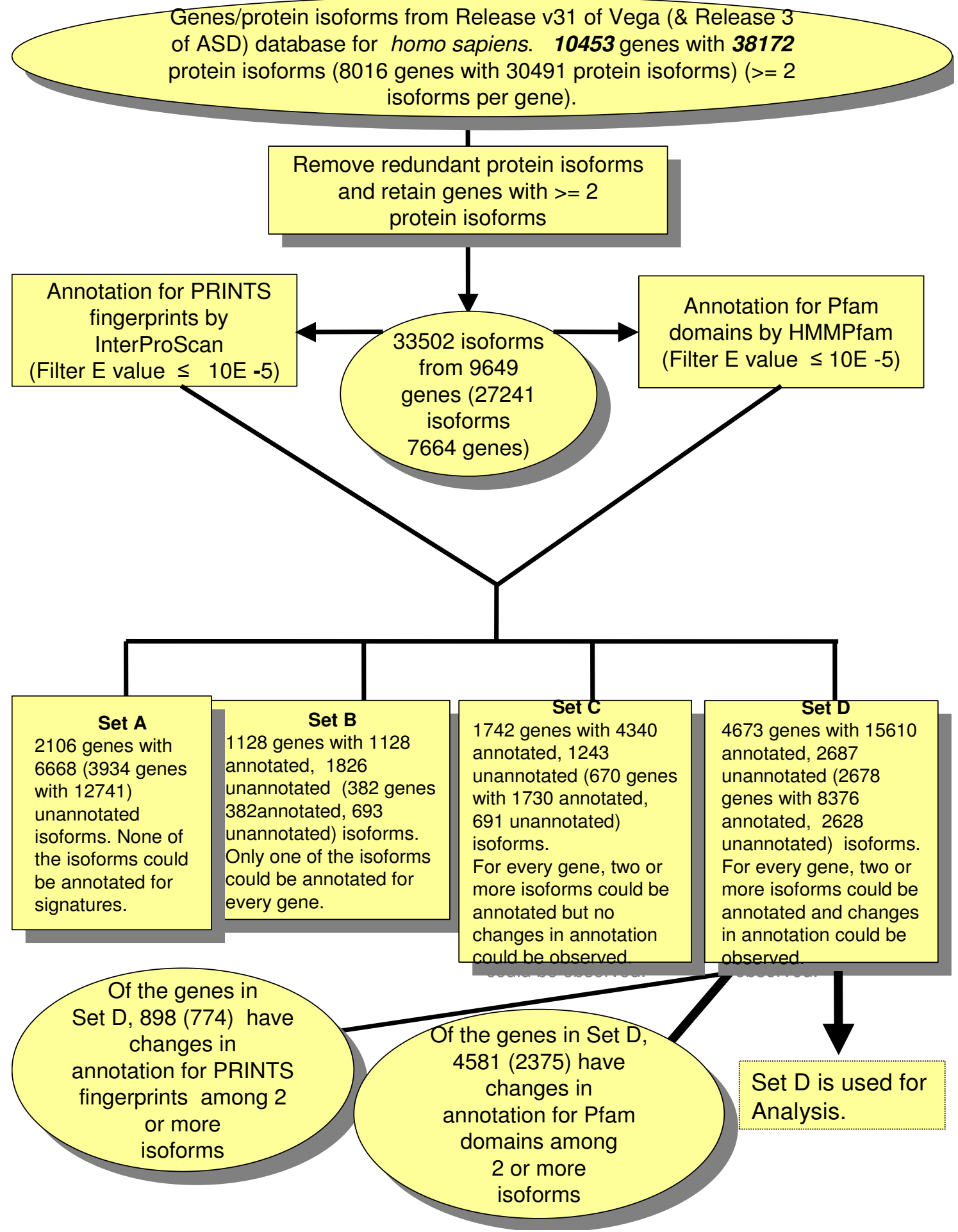

\section{Figure 2}

Flow of data (on genes and protein isoforms) through methodological steps adopted to derive the Set D used for characterizations. The numbers given in red correspond to the ASD data set, and those given in print colour correspond to the Vega data set. The number of genes in Set D forms $44.7 \%$ (33.4\% in the case of ASD) of the genes from the startup data set, the number of (PRINTS and Pfam) annotated protein isoforms and unannotated protein isoforms form $41 \%$ and $7 \%$ ( $27.5 \%$ and $8.6 \%$ in the case of ASD), respectively of the isoforms from the start-up data set. 
the overlapping fingerprints from same top-level classification (in ASD data set, the numbers are 552 and 472). We raised a question as to how often alternative splicing removes overlaps? We examined isoform pairs where one or both the partners are from this set of peptides with overlapping annotation. In 1548 instances of 2036 such pairs from Vega data set, alternative splicing removed the overlapping fingerprint(s) (in ASD data set, the numbers are 788 of 1242) - this phenomenon can be considered as an event by itself (though it can be treated as fingerprint insertion/deletion).

\section{Insertion/deletion, and truncation of fingerprints}

Changes in fingerprints among the annotated protein isoforms were seen in a data set of 898 Vega and 774 ASD genes. Classification of PRINTS events as insertions/deletion of fingerprints (Classes $\mathrm{A}$ and $\mathrm{C}$ events), and truncation (Classes B \& D events) (see the section on Methods) is informative in terms of severity of the effects on the function. Insertion/deletion events, where a fingerprint (seen with all or some of the constituent motifs) is totally lost between two isoform sequences, may bring severe effects as compared to the other type (namely truncation, where the fingerprint can still be seen in both the isoform sequences albeit with differing number of constituent motifs). Our data sets show that truncation of fingerprints occurs in more number of genes than insertion/deletion of fingerprints; truncation occurs in 848 Vega (in 734 ASD) genes while insertion/deletion occurs in 242 Vega (in 226 ASD) genes. Since truncation events are seen in a large number of genes, it could be that truncation of fingerprints is a mechanism to modulate protein functionalities. It is to be mentioned here that the presented fingerprint truncation phenomenon is different from the $\mathrm{N}$-terminal and C-terminal protein shortening (or truncation) that the splicing community talk about - it is usually the case that in such protein shortenings, a signature is completely lost. It is significant if the observed fingerprint truncations are often seen not as part of the $\mathrm{N}$ - or C-terminal shortenings but are seen in the internal regions of the shorter isoforms. We examined how often the observed truncations of fingerprints are results of $\mathrm{N}$-, or C-terminal protein shortenings as opposed to genuine internal truncations. We define the fingerprint truncation as part of $\mathrm{N}$ or C-terminal protein shortening, if the number of amino acid residues separating the truncated end of the fingerprint from the corresponding terminal of the shorter protein by less than 5 amino acids. The ratios of observed truncations were seen as (part of $\mathrm{N}$-terminal shortening : genuine internal : part of C-terminal shortening $=1: 7.6$ : 1.5 in the case of ASD genes, and $1: 8.8: 1.9)$. Thus the fingerprint truncations are not mainly due to alternative start/stop codons. Table 1 lists the top-level classifications of fingerprints that often undergo insertion/deletion and truncation events in our data set; it is seen that the major classes of fingerprints that undergo insertion/deletion/ truncation events are receptors, enzymes (hydrolases, oxidoreductases, and transferases), transport proteins, structural proteins, RNA- or DNA-associated proteins, and 'Domain' signatures (such as those of $\mathrm{SH} 2 / \mathrm{SH} 3$, Ankyrin, Apple and Kringle domains - see [40] for a list). The topranking fingerprints from the above-mentioned classes are signatures of: SH2 domain signature, C4-type steroid receptor zinc finger signature, Steroid hormone receptor signature, P450 superfamily signature, Neurotransmittergated ion channel family signature, Secretin-like GPCR family signature, Tyrosine kinase catalytic domain signature, and Short-chain dehydrogenase/reductase (SDR) superfamily signature (See additional file 1: Additional File 1 for a list of top 10 frequently observed fingerprints that undergo insertion/deletion event among protein isoforms).

\section{Swapping, and Reshuffle of fingerprints}

In addition to the above-mentioned insertion/deletion and truncation events, we looked for other events such as swap (where a fingerprint seen, either as 'complete' or 'partial', in a protein sequence is swapped with another in the isoform sequence), and reshuffle (where the positional ordering of fingerprints as seen in a protein sequence is reversed in the isoform sequence). Just one instance of swap was seen (in ASD data set; Vega data set showed 4 instances but they are ambiguous because the protein isoform is annotated with fingerprints that overlap in positions) and one instance of reshuffle (in Vega data set - reshuffling among SH2DOMAIN and SH3DOMAIN) event was observed.

\section{Splice-mediated events with Pfam domains among protein isoforms}

Relative frequencies of different splice events with domains

We observed splicing events associated with Pfam domains in 4581 Vega and 2375 ASD genes. Truncation in domain length is the most predominant event (at 54\% of the instances of Vega protein isoform pairs, at 35\% of the instances of ASD protein isoforms pairs) followed by insertion/deletion of domains (at $46 \%$ of the instances of Vega protein isoform pairs, at $29 \%$ of the instances of ASD protein isoform pairs). Swapping of domains occurred in few instances (56 Vega isoform pairs and 9 ASD isoform pairs). Reshuffling of domains was observed in just one pair of protein isoforms. Occurrence of truncation events in a large number of instances can probably be associated with regulation, while insertion/deletion events can be associated with a regulation activity ranging from finetuning to drastic changes (depending on the nature of the domain and the context of the splicing event). 
Table I: Classifications of fingerprints involved in insertion/deletion and truncation events.

\begin{tabular}{|c|c|c|c|c|}
\hline \multirow{3}{*}{$\begin{array}{l}\text { Top-level PRINTS classifications of } \\
\text { fingerprints }\end{array}$} & \multicolumn{4}{|c|}{ No. of observed events* affecting } \\
\hline & \multicolumn{2}{|c|}{ the whole fingerprint ${ }^{\&}$} & \multicolumn{2}{|c|}{ some of the constituent motifs of the fingerprint $\$$} \\
\hline & $\begin{array}{l}\text { Type } A \text { - insertion/ } \\
\text { deletion of a } \\
\text { 'complete' fingerprint }\end{array}$ & $\begin{array}{l}\text { Type } \mathrm{C} \text { - insertion/ } \\
\text { deletion of a } \\
\text { 'partial' fingerprint }\end{array}$ & $\begin{array}{l}\text { Type B - truncation } \\
\text { of a 'complete' to } \\
\text { 'partial' fingerprint }\end{array}$ & $\begin{array}{l}\text { Type } D \text { - fingerprint is } \\
\text { partial in both the } \\
\text { isoforms and possess differing } \\
\text { number of constituent motifs }\end{array}$ \\
\hline \multirow[t]{2}{*}{ Receptors } & $\underline{61}(23 \%)$ & $\underline{23}(8 \%)$ & $\underline{159}(62 \%)$ & $\underline{13}(5 \%)$ \\
\hline & $\underline{64}(22 \%)$ & $\underline{33}(1 / \%)$ & $153(54 \%)$ & $\underline{33}(1 / \%)$ \\
\hline \multirow[t]{2}{*}{ Enzymes: Hydrolases } & $11(9 \%)$ & $4(3 \%)$ & $\underline{90}(79 \%)$ & $8(7 \%)$ \\
\hline & $13(10 \%)$ & $2(1 \%)$ & $97(73 \%)$ & $19(14 \%)$ \\
\hline \multirow[t]{2}{*}{ Transport proteins:others } & $\underline{51}(27 \%)$ & $\underline{15}(7 \%)$ & $\underline{100}(53 \%)$ & $\underline{22}(/ 1 \%)$ \\
\hline & $\underline{27}(19 \%)$ & $\underline{21}(15 \%)$ & $\underline{77}(55 \%)$ & $\overline{15}(10 \%)$ \\
\hline \multirow[t]{2}{*}{ Enzymes: Oxidoreductases } & $17(18 \%)$ & $11(1 / \%)$ & $39(41 \%)$ & $\underline{27}(28 \%)$ \\
\hline & $11(10 \%)$ & $\underline{19}(18 \%)$ & $40(38 \%)$ & $\underline{34}(32 \%)$ \\
\hline \multirow[t]{2}{*}{ Enzymes: Transferases } & $13(14 \%)$ & $3(3 \%)$ & $69(78 \%)$ & $3(3 \%)$ \\
\hline & $17(18 \%)$ & $5(5 \%)$ & $\underline{63}(68 \%)$ & $7(7 \%)$ \\
\hline \multirow[t]{2}{*}{ Structural proteins } & $\underline{26}(15 \%)$ & $\underline{12}(7 \%)$ & $\underline{107}(62 \%)$ & $\underline{26}(15 \%)$ \\
\hline & $13(14 \%)$ & $6(6 \%)$ & $\underline{49}(55 \%)$ & $\underline{20}(22 \%)$ \\
\hline \multirow[t]{2}{*}{ RNA- or DNA-associated proteins } & $17(15 \%)$ & $3(2 \%)$ & $67(62 \%)$ & $\underline{20}(18 \%)$ \\
\hline & $\overline{17}(23 \%)$ & $2(2 \%)$ & $44(60 \%)$ & $\overline{10}(13 \%)$ \\
\hline \multirow[t]{2}{*}{ PRINTS 'Domains' signatures } & $\underline{20}(36 \%)$ & $\underline{13}(23 \%)$ & 21 (38\%) & $I(I \%)$ \\
\hline & $\underline{26}(52 \%)$ & $4(8 \%)$ & $17(34 \%)$ & $3(6 \%)$ \\
\hline \multirow[t]{2}{*}{ Cytokines and growth factors } & $\overline{4}(14 \%)$ & $2(7 \%)$ & $17(62 \%)$ & $4(14 \%)$ \\
\hline & $6(18 \%)$ & $3(9 \%)$ & $22(66 \%)$ & $2(6 \%)$ \\
\hline \multirow[t]{2}{*}{ Protein secretion and chaperones } & $0(0 \%)$ & $2(14 \%)$ & $8(57 \%)$ & $4(28 \%)$ \\
\hline & $0(0 \%)$ & $6(26 \%)$ & II (47\%) & $6(26 \%)$ \\
\hline
\end{tabular}

*, Events of same insertion/deletion type involving fingerprint members of a PRINTS classification observed among multiple pairs of isoforms from a gene are counted as one. Per every type of insertion/deletion event, the observed numbers involving the five top scoring fingerprint PRINTS classification are underlined. In brackets are given values on what fraction of events involving the PRINTS classification is of the given insertion/ deletion type - values $>=35 \%$ are in bold; values $<=15 \%$ are in italics. Values for Vega data set are given in line I and values for ASD data set are given in line 2 in every row.

\&, A fingerprint seen as either 'complete' (with all the constituent motifs) or 'partial' (with only some of the constituent motifs) in an isoform is deleted in the other isoform.

$\$$, Some of the constituent motifs of a fingerprint ('complete' or 'partial') in an isoform are deleted in the other isoform.

\section{Truncation of domains}

Examination of protein isoform sequences for domains that are expressed in different lengths revealed that the data on domain truncations is more complex than we expected; even when a region (corresponding to a domain) is shortened by large extents, it is annotated by HmmPfam for the same domain. Table 2 lists Pfam domains that frequently undergo truncation (show different lengths in protein isoforms) as ranked by the number of genes encoding the domain in different lengths among the protein isoforms. In each of the cases of listed domains, a high percent fraction of the genes encoding the domain exhibit domain truncation. In each case of domains, a large number of variations in lengths is observed; highest number of variations is seen in the cases of Pkinase (52 variants), MFS_1 (33 variants), Serpin (30 variants), Trypin (23 variants) and Filament (23 variants) domains. Examination of data on the extent of variation in the lengths of regions, that could still be annotated for same domains, reveals that the variation can be extensive - e.g. a variation of more than 100 amino acid residues could be seen in the cases of domains Pkinase, MHC_I, Filament, PH, etc. Since a large number of domains (Vega: 1552 of 2057 distinct annotated domains; ASD: 1149 of 1592 distinct annotated domains) are seen to undergo truncations in a large number of genes (Vega: 3532 of 4581 genes; ASD: 1779 of 2375 genes), it could mean that truncation could be a mechanism to modulate the processes in which they are involved. As in the case of fingerprint truncations, we observe here that domain truncations are not mainly due to $\mathrm{N}$ - or C-terminal shortenings of the proteins; the ratios of observed domain truncations are seen as (part of $\mathrm{N}$-terminal shortening : genuine internal : part of C-terminal shortening $=1.5: 4$ : 1 ). Thus the domain truncations are not mainly due to alternative start/stop codons.

\section{Insertion/Deletion of domains}

We find that 933 of 2057 distinct annotated domains in Vega (ASD: 673 of 1592 distinct annotated domains) undergo insertion/deletion. Table 3 lists the top 20 domains that are often inserted or deleted among protein 
Table 2: Pfam domains that are frequently truncated among protein isoforms.

\begin{tabular}{|c|c|c|c|c|}
\hline \multirow[t]{2}{*}{ Domain } & \multirow{2}{*}{$\begin{array}{l}\text { No. of genes that encode the domain } \\
\text { in different lengths among the protein } \\
\text { isoforms ( } \& \text { as percentage fraction of genes } \\
\text { encoding the domain in the protein isoforms) } \$\end{array}$} & \multirow[t]{2}{*}{$\begin{array}{l}\text { Count of unique } \\
\text { domain lengths @ }\end{array}$} & \multicolumn{2}{|c|}{$\begin{array}{l}\text { Variation in lengths of } \\
\text { the domain among isoforms }\end{array}$} \\
\hline & & & Minimal length & Maximal length \\
\hline \multirow[t]{2}{*}{ Pkinase } & II 6 (77\%) & 52 & 23 & 572 \\
\hline & $3(8 \%)$ & 5 & 199 & 486 \\
\hline \multirow[t]{2}{*}{$\mathrm{Cl}$-set } & 47 (43\%) & & & \\
\hline & Not seen in ASD & 8 & 30 & 89 \\
\hline \multirow[t]{2}{*}{ Ras } & $38(92 \%)$ & & & \\
\hline & Not seen in ASD & 21 & 25 & 192 \\
\hline \multirow[t]{2}{*}{ MHC_I } & 35 (70\%) & 7 & 36 & 178 \\
\hline & $3(60 \%)$ & 5 & 91 & 178 \\
\hline \multirow[t]{2}{*}{ Trypsin } & $29(60 \%)$ & 23 & 32 & 261 \\
\hline & $20(66 \%)$ & 14 & 104 & 261 \\
\hline \multirow[t]{2}{*}{$A B C$ tran } & $29(80 \%)$ & 15 & 55 & 197 \\
\hline & $11(68 \%)$ & 9 & 80 & 199 \\
\hline \multirow[t]{2}{*}{ Filament } & 26 (92\%) & 23 & 34 & 452 \\
\hline & $4(100 \%)$ & 6 & 142 & 400 \\
\hline \multirow[t]{2}{*}{$\mathrm{PH}$} & $24(25 \%)$ & 15 & 26 & 241 \\
\hline & $6(15 \%)$ & 5 & 84 & 134 \\
\hline \multirow[t]{2}{*}{ MFS_I } & $23(92 \%)$ & 33 & 82 & 537 \\
\hline & $6(54 \%)$ & 7 & 326 & 426 \\
\hline \multirow[t]{2}{*}{ Serpin } & 22 (100\%) & 30 & 31 & 424 \\
\hline & 10 (100\%) & 13 & 140 & 378 \\
\hline \multirow[t]{2}{*}{ P450 } & $22(100 \%)$ & 22 & 86 & 463 \\
\hline & $13(72 \%)$ & 20 & 187 & 486 \\
\hline \multirow[t]{2}{*}{ Proteasome } & $22(100 \%)$ & 11 & 29 & 191 \\
\hline & $9(100 \%)$ & 8 & 117 & 187 \\
\hline \multirow[t]{2}{*}{$7 \mathrm{tm} \_\mathrm{I}$} & $22(70 \%)$ & 24 & 25 & 459 \\
\hline & $16(48)$ & 17 & 149 & 388 \\
\hline \multirow[t]{2}{*}{ lon_trans } & $21(63)$ & 18 & 27 & 280 \\
\hline & I (I0\%) & 2 & 208 & 220 \\
\hline \multirow[t]{2}{*}{ RRM_I } & $20(46 \%)$ & 9 & 23 & 86 \\
\hline & $9(34 \%)$ & 4 & 46 & 72 \\
\hline \multirow[t]{2}{*}{ DEAD } & $19(67 \%)$ & 17 & 27 & 188 \\
\hline & $9(56 \%)$ & 9 & 96 & 180 \\
\hline \multirow[t]{2}{*}{ Pkinase_Tyr } & $19(38 \%)$ & & & \\
\hline & Not seen in ASD & 17 & 50 & 301 \\
\hline \multirow[t]{2}{*}{ Collagen } & $19(37 \%)$ & & & \\
\hline & Not seen in ASD & 5 & 28 & 59 \\
\hline \multirow[t]{2}{*}{ Tubulin } & $18(100 \%)$ & 13 & 46 & 227 \\
\hline & $2(50 \%)$ & 5 & 113 & 227 \\
\hline I-set & $18(37 \%)$ & & & \\
\hline & Not seen in ASD & 10 & 22 & 99 \\
\hline Helicase_C & $18(35 \%)$ & 7 & 41 & 91 \\
\hline & $3(12 \%)$ & 3 & 55 & 76 \\
\hline Mito_carr & $17(73 \%)$ & 14 & 26 & 146 \\
\hline & $13(65 \%)$ & 10 & 50 & 136 \\
\hline UQ_con & 7 (87\%) & 8 & 28 & 144 \\
\hline & $12(100 \%)$ & 11 & 69 & 157 \\
\hline
\end{tabular}

$\$$, presents the number of genes that encode the domain as undergoing truncation event among the protein isoforms. In brackets, is given in terms of percentage fraction of genes that encode the domain in the protein isoforms. Values with Vega data set is shown in line I, and values with ASD data set is shown in line 2.

@, the observed lengths were grouped in a manner that any two lengths that differ by 5 or less amino acids is considered as one unique length. 
Table 3: Top 20 Pfam domains that are often inserted or deleted among protein isoforms*.

\begin{tabular}{|c|c|c|c|c|}
\hline Pfam Domain & No. of genes\$ & $\begin{array}{l}\text { Pfam Description of the } \\
\text { domain }\end{array}$ & Associated GO terms & $\begin{array}{l}\text { Keywords associated with } \\
\text { the domain }\end{array}$ \\
\hline \multirow[t]{2}{*}{$\mathrm{zf}-\mathrm{C} 2 \mathrm{H} 2$} & $104(75 \%)$ & Zinc finger, $\mathrm{C} 2 \mathrm{H} 2$ type & Zinc ion binding & Nucleic Acid binding \\
\hline & $61(48 \%)$ & & & \\
\hline \multirow[t]{2}{*}{$\mathrm{PH}$} & $59(62 \%)$ & pleckstrin homology & & $\begin{array}{l}\text { Intracellular signaling/ } \\
\text { constituent of cytoskeleton }\end{array}$ \\
\hline & $22(44 \%)$ & & & \\
\hline \multirow[t]{2}{*}{ Ank } & $54(80 \%)$ & Ankyrin repeat & & Protein-protein interaction \\
\hline & $25(34 \%)$ & & & \\
\hline \multirow[t]{2}{*}{ ig } & $51(82 \%)$ & Immunoglobulin family & & $\begin{array}{l}\text { Domains for cell surface } \\
\text { recognition. }\end{array}$ \\
\hline & Not seen in asd & & & \\
\hline \multirow{2}{*}{ fn3 } & $46(77 \%)$ & Fibronectin type III domain & & Multi-domain glycoproteins. \\
\hline & $6(28 \%)$ & & & \\
\hline \multirow[t]{2}{*}{ SPRY } & $46(77 \%)$ & SPla and the Ryanodine receptor & & \\
\hline & $3(75 \%)$ & & & \\
\hline \multirow[t]{2}{*}{ Collagen } & $45(88 \%)$ & Collagen triple helix repeat & Phosphate transport & Extracellular structural proteins \\
\hline & $8(66 \%)$ & & & \\
\hline \multirow[t]{2}{*}{$\mathrm{zf}-\mathrm{C} 3 \mathrm{HC} 4$} & $44(61 \%)$ & $\begin{array}{l}\text { Zinc finger, C3HC4 type } \\
\text { (RING finger) }\end{array}$ & Protein binding, zinc ion binding & $\begin{array}{l}\text { Key role in ubiquitination } \\
\text { pathway. }\end{array}$ \\
\hline & $7(50 \%)$ & & & \\
\hline \multirow[t]{2}{*}{ Pkinase } & $44(29 \%)$ & Protein kinase domain & $\begin{array}{l}\text { ATP binding, protein kinase } \\
\text { activity, protein amino acid } \\
\text { phosphorylation }\end{array}$ & \\
\hline & I (2\%) & & & \\
\hline \multirow[t]{2}{*}{ PDZ } & $43(66 \%)$ & PDZ domain & Protein binding & Signaling \\
\hline & $18(42 \%)$ & & & \\
\hline \multirow[t]{2}{*}{ KRAB } & $42(46 \%)$ & $\begin{array}{l}\text { Kruppel-associated box present } \\
\text { in proteins containg } \mathrm{C} 2 \mathrm{H} 2 \\
\text { fingers. }\end{array}$ & $\begin{array}{l}\text { Nucleic acid binding, } \\
\text { intracellular, DNA-dependent } \\
\text { regulation of transcription }\end{array}$ & Protein-protein interactions \\
\hline & $34(49 \%)$ & & & \\
\hline \multirow[t]{2}{*}{$\mathrm{Cl}$-set } & $4 \mathrm{I}(37 \%)$ & Immunoglobulin $\mathrm{Cl}$-set domain & & $\begin{array}{l}\text { Cell-cell recognition, cell- } \\
\text { surface receptors, muscle } \\
\text { structure, immune system. }\end{array}$ \\
\hline & I (50\%) & & & \\
\hline \multirow[t]{2}{*}{ WD40 } & $40(83) \%$ & WD or beta-transducin repeats & & $\begin{array}{l}\text { Signal transduction, } \\
\text { transcription regulation, cell } \\
\text { cycle control, apoptosis. }\end{array}$ \\
\hline & $35(38 \%)$ & & & \\
\hline \multirow[t]{2}{*}{ EGF } & $40(83 \%)$ & $\begin{array}{l}\text { Epidermal growth factor - like } \\
\text { domain }\end{array}$ & & Found in extracellular domain. \\
\hline & $5(18 \%)$ & & & \\
\hline \multirow[t]{2}{*}{ SH3_I } & $40(51 \%)$ & Src homology 3 & & Signal transduction \\
\hline & $4(8 \%)$ & & & $\begin{array}{l}\text { related to cytoskeletal } \\
\text { organisation. }\end{array}$ \\
\hline \multirow[t]{2}{*}{ Sushi } & $39(97 \%)$ & $\begin{array}{l}\text { Complement control protein } \\
(\mathrm{CCP}) \text { modules, or short } \\
\text { consensus repeats (SCR). }\end{array}$ & & Complement and adhesion \\
\hline & 17 (73\%) & & & \\
\hline \multirow[t]{2}{*}{ Helicase_C } & $32(62 \%)$ & $\begin{array}{l}\text { Helicase conserved C-terminal } \\
\text { domain }\end{array}$ & Nucleic acid binding & Helicase \\
\hline & $12(44 \%)$ & & & \\
\hline \multirow[t]{2}{*}{ I-set } & $32(66 \%)$ & Immunoglobulin I-set domain & & $\begin{array}{l}\text { Cell-cell recognition, cell- } \\
\text { surface receptors, muscle } \\
\text { structure, immune system }\end{array}$ \\
\hline & Not present in ASD & & & \\
\hline \multirow[t]{2}{*}{ RRM_I } & $31(72 \%)$ & RNA recognition motif & Nucleic Acid binding & RNA binding \\
\hline & $21(46 \%)$ & & & \\
\hline \multirow[t]{2}{*}{ C2 } & 27 (61\%) & $\begin{array}{l}\mathrm{Ca} 2+- \text { dependent membrane- } \\
\text { targeting module }\end{array}$ & & $\begin{array}{l}\text { Signal transduction/membrane } \\
\text { trafficking }\end{array}$ \\
\hline & $16(53 \%)$ & & & \\
\hline LIM & $19(82 \%)$ & LIM domain (Binding protein) & Zinc ion binding & $\begin{array}{l}\text { Interface for protein-protein } \\
\text { interaction }\end{array}$ \\
\hline
\end{tabular}


Table 3: Top 20 Pfam domains that are often inserted or deleted among protein isoforms*. (Continued)

\begin{tabular}{|c|c|c|c|c|}
\hline & $20(74 \%)$ & & & \\
\hline \multirow[t]{2}{*}{ Mito_carr } & $21(91 \%)$ & Mitochondrial carrier & Transport, binding, membrane & \\
\hline & $19(86 \%)$ & & & \\
\hline \multirow[t]{2}{*}{$\mathrm{CH}$} & $16(53 \%)$ & Calponin homology domain & & Cytoskeletal/signal transduction \\
\hline & $12(66 \%)$ & & & \\
\hline \multirow[t]{2}{*}{ Hormone_receptor } & $9(32 \%)$ & $\begin{array}{l}\text { Ligand-binding domain of nuclear } \\
\text { hormone receptor }\end{array}$ & $\begin{array}{l}\text { Transcription factor; regulation } \\
\text { of transcription }\end{array}$ & Hormone binding \\
\hline & $12(60 \%)$ & & & \\
\hline \multirow[t]{2}{*}{ Trypsin } & $20(41 \%)$ & Trypsin & Proteolysis & Proteolytic enzyme \\
\hline & II (30\%) & & & \\
\hline
\end{tabular}

$\$$, presents the number of genes in which the domain is seen as undergoing domain insertion/deletion event. In brackets, is given in terms of percentage fraction of genes containing the domain - in what percentage fraction of genes (that contain the domain), the domain undergoes insertion/deletion.

*, Line I gives values from Vega data set and line 2 gives values from ASD data set.

isoforms. Examination of Gene Ontology (GO) terms [41] and Pfam descriptions associated with these domains reveals that the top three affected molecular processes are: (i) regulation of transcription, as indicated by the appearance of nucleic acid binding domains (such as zf-C2H2, KRAB, WD40, RRM_1, and Helicase_C). (ii) signal transduction as indicated by the appearance of domains such as WD40, PDZ, PH, C2, CH, and SH3_1; and (iii) proteinprotein interaction as indicated by the appearance of domains such as Ank, LRR_1, LIM, and KRAB. Apart from these three major categories, we find cellular adhesion \& recognition (as indicated by the appearance of the Sushi, ig, collagen, C1-set, EGF, I-set, and domains), and proteolysis as affected by domain insertion/deletion events. These functional "categories" (nucleic acid binding, signal transduction and protein-protein interaction) represent key functions that include control of gene expression, intercellular relationships or cellular signaling, and basic molecular interactions of many biological processes. Protein isoforms affected by such insertion/deletion splicing events probably act as molecular switches where a specific function has to be quickly switched off - as substantiated by literature reports that some spliced isoforms lacking an exon (or a domain in our study) can have antagonist effect (such as in the case of caspase-9 protease: the constitutive form of the protein induces apoptosis, while its shorter isoform acts as an inhibitor $[42,43])$.

\section{Domain swapping}

Variations in protein isoforms due to domain swapping are less frequent as compared to domain insertion/deletion and truncation events. We identified 65 instances of protein isoform pairs (See additional file 2: Additional File 2 for the list of these protein isoform pairs) wherein a domain alternates with another. These 65 instances (3 from ASD data set and 62 from Vega data set) form a list of 35 unique pairs of alternating domains (see Table 4). Though the isoform sequences show repeats of domains in 59 of these 65 instances of isoform pairs, it is fair to believe that the domains patterns can be unambiguously aligned to extract the swap events (we have marked these instances in the database with a note as containing repeats). Examination of the description of the alternating domains (Table 4) reveals that a domain alternates often with a domain of same structural or functional classification; swapping between such similar domains probably fine-tune the biological process - some of these exemplary pairs are: (Hormone_receptor, zf-C4; KRAB, zfC2H2; SCAN, zf-C2H2Ion_trans, Ion_trans_2; ig, I-set; Iset, V-set, EGF_CA, EGF, etc).

\section{Reshuffling of domains}

No reshuffling event involving domains was observed in our data sets.

\section{Comparison among different events involving domains}

Table 5 compares the gene and event distributions for different Pfam domains; the table illustrates a trend that certain domains show preference of an event over other types of events. Some of the domains that particularly undergo insertion/deletion events in a higher percent fraction of genes (containing the specific domain) as compared to truncation events are: zf-C2H2, PH, Ank, SPRY, KRAB, WD40, Sushi and EGF. Domains that particularly undergo truncation events in a higher percent fraction of genes (containing the specific domain) as compared to insertion/deletion events: Trypsin, Ras, MHC_1 and ABC_tran.

\section{Use of both PRINTS and Pfam resources for annotating the protein isoforms}

Examination of the genes and isoforms from Set D (that is used for the analysis) indicate that PRINTS could annotate 898 Vega (774 ASD) genes with detectable changes in fingerprints among isoforms, and Pfam could annotate 4583 Vega (2375 ASD) genes with detectable changes in domains among isoforms. While only in the case of 9 Vega and 27 ASD genes none of the encoded protein isoforms could be annotated for Pfam domains, in the case of 2729 Vega and 1466 ASD genes none of the encoded protein isoforms could be annotated for PRINTS fingerprints. As mentioned through in earlier sections, the observations/interpretations (e.g. truncations being the 
Table 4: Unique pairs of alternating Pfam domains

\begin{tabular}{|c|c|c|c|}
\hline \multicolumn{4}{|c|}{ Domains participating in Swap Events (DI <--> D2) } \\
\hline Domain DI & Domain D2 & Description of Domain DI & Description of Domain D2 \\
\hline Hormone_receptor & $\mathrm{zf}-\mathrm{C} 4$ & $\begin{array}{l}\text { Ligand-binding domain of nuclear hormone } \\
\text { receptor. Steroid hormone receptor activity; } \\
\text { transcription factor activity. DNA-dependent } \\
\text { regulation of transcription. }\end{array}$ & $\begin{array}{l}\text { Zinc finger C4 type. Found in steroid/thyroid } \\
\text { hormone receptors; transcription factor } \\
\text { activity. Regulation of transcription. }\end{array}$ \\
\hline KRAB & $\mathrm{Zf}-\mathrm{C} 2 \mathrm{H} 2$ & $\begin{array}{l}\text { Kruppel-associated box. Nucleic Acid binding; } \\
\text { DNA dependent regulation of transcription. }\end{array}$ & Zinc finger. Nucleic acid binding. \\
\hline SCAN & $\mathrm{zf}-\mathrm{C} 2 \mathrm{H} 2$ & $\begin{array}{l}\text { SCAN domain (named after SRE-ZBP, CTfin5I, } \\
\text { AW-I and Number I } 8 \text { cDNA). Found in several zf- } \\
\mathrm{C} 2 \mathrm{H} 2 \text { proteins. DNA dependent regulation of } \\
\text { transcription. }\end{array}$ & $\begin{array}{l}\text { Zinc finger, } \mathrm{C} 2 \mathrm{H} 2 \text { type. Zinc ion binding; } \\
\text { nucleic acid binding. }\end{array}$ \\
\hline Mito_carr & efhand & Mitochondrial carrier. Transport & $\begin{array}{l}\text { EF hand. Calcium ion binding. Signaling. } \\
\text { Buffering/transport. }\end{array}$ \\
\hline $\mathrm{CH}$ & Plectin & $\begin{array}{l}\text { Calponin homology domain. Actin-binding family. } \\
\text { Cytoskeletal/signal transduction }\end{array}$ & $\begin{array}{l}\text { Plectin repeat. Found in Plakin proteins. Plasma } \\
\text { and nuclear membrances. }\end{array}$ \\
\hline sushi & CUB & $\begin{array}{l}\text { Sushi domain (SCR repeat) Complement control } \\
\text { protein (CCP) modules, or short consensus } \\
\text { repeats (SCR). Complement and adhesion. }\end{array}$ & $\begin{array}{l}\text { Structural motif in extracellular and plasma } \\
\text { membrane-associated proteins. }\end{array}$ \\
\hline RGS & PDZ & Regulator of $\mathrm{G}$ protein signaling domain. & PDZ domain. Protein binding. Signaling \\
\hline $\mathrm{C} 2$ & PDZ & $\begin{array}{l}\mathrm{Ca} 2+\text {-dependent membrane-targeting module. } \\
\text { Signal transduction/membrane trafficking }\end{array}$ & PDZ domain. Protein binding. Signaling \\
\hline collagen & emi & $\begin{array}{l}\text { Collagen triple helix repeat. Phosphate transport. } \\
\text { Extracellular structural proteins }\end{array}$ & Found in extracellular proteins. \\
\hline Nebulin & LIM & $\begin{array}{l}\text { Nebulin repeat. Found in the thin filaments of } \\
\text { striated vertebrate muscle. Actin-binding protein. }\end{array}$ & $\begin{array}{l}\text { LIM domain (Binding protein). Zinc ion binding. } \\
\text { Interface for protein-protein interaction }\end{array}$ \\
\hline $\mathrm{PH}$ & Pkinase_Tyr & $\begin{array}{l}\text { pleckstrin homology. Intracellular signaling/ } \\
\text { constituent of cytoskeleton. Pkinase_tyr supposed } \\
\text { to contain } \mathrm{PH} \text { domains. }\end{array}$ & $\begin{array}{l}\text { Protein tyrosine kinase. Mediates the response } \\
\text { to external stimuli. }\end{array}$ \\
\hline Tubulin-binding & MAP2_projctn & Tau and MAP protein. Tubulin-binding repeat. & MAP domain (MHC class II analogue protein) \\
\hline FHA & $\mathrm{BRCT}$ & $\begin{array}{l}\text { Forkhead-associated domain. Phosphopeptide } \\
\text { binding motif }\end{array}$ & $\begin{array}{l}\text { BRCAI C terminus domain. Phospho-protein } \\
\text { binding protein. }\end{array}$ \\
\hline NTP_transf_2 & PAP_RNA-bind & Nucleotidyltransferase domain. & $\begin{array}{l}\text { Poly }(\mathrm{A}) \text { polymerase predicted RNA binding } \\
\text { domain. Polynucleotide adenyltransferase } \\
\text { activity. }\end{array}$ \\
\hline lon_trans & lon_trans_2 & lon transport protein & Ion channel. Both are of same clan. \\
\hline Orn_Arg_deC_N & Orn_DAP_Arg_deC & $\begin{array}{l}\text { Pyridoxal-dependent decarboxylase, pyridoxal } \\
\text { binding domain. Catalytic activity }\end{array}$ & $\begin{array}{l}\text { Pyridoxal-dependent decarboxylase, C-terminal } \\
\text { sheet domain. Catalytic activity. }\end{array}$ \\
\hline MAM & ig & $\begin{array}{l}\text { Adhesive function. Cellular component: } \\
\text { membrance }\end{array}$ & Immunoglobulin domain \\
\hline ig & I-set & Immunoglobulin & $\begin{array}{l}\text { Immunoglobulin intermediate. Both are of same } \\
\text { clan. }\end{array}$ \\
\hline l-set & V-set & $\begin{array}{l}\text { Immunoglobulin I-set (intermediate) domain. I-set } \\
\text { and V-set are of same clan. }\end{array}$ & Immunoglobulin V-set (variable) domain. \\
\hline EGF_CA & EGF & Calcium binding EGF domain. & EGF-like protein. Both are of same clan. \\
\hline Hydrolase & EI-E2_ATPase & $\begin{array}{l}\text { Haloacid dehalogenase-like hydrolase. Catalytic } \\
\text { activity. Metabolic process }\end{array}$ & Hydrolase activity. ATP binding. \\
\hline Radical_SAM & Mob_synth_C & Catalytic activity; iron-sulfur cluster binding. & $\begin{array}{l}\text { Molybdenum cofactor synthesis C. iron, sulfur } \\
\text { cluster binding }\end{array}$ \\
\hline Aconitase & Aconitase_C & Aconitase hydratase. Lyase activity. & Aconitase hydratase. Hydro-lyase activity. \\
\hline Filament & Filament_head & $\begin{array}{l}\text { Intermediate filament protein. Structural molecule } \\
\text { activity }\end{array}$ & Head region of intermediate filaments. \\
\hline $\mathrm{CNH}$ & Pkinase & $\begin{array}{l}\text { Citron and Citron kinase. Small GTPase regulator } \\
\text { activity. }\end{array}$ & Protein kinase activity. ATP binding. \\
\hline PSI & Sema & Plexin repeat. Membrane. Receptor activity & $\begin{array}{l}\text { Semaphorins. Secreted and transmembrane } \\
\text { proteins. }\end{array}$ \\
\hline GTP_EFTU_D2 & GTP_EFTU & Elongation factor & GTP binding. Elongation factor \\
\hline PARP & WWE & $\begin{array}{l}\text { Poly(ADP-ribose) polymerase. Catalyses covalent } \\
\text { attachment of ADP-ribose to DNA binding }\end{array}$ & $\begin{array}{l}\text { Mediates protein-protein interactions in } \\
\text { ubiquitin and ADP ribose conjugation system. }\end{array}$ \\
\hline
\end{tabular}

Sushi An_peroxidase proteins

Complement control protein (CCP) modules, or short consensus repeats (SCR). Complement and adhesion

Animal haem peroxidase. Peroxidase activity. 
Table 4: Unique pairs of alternating Pfam domains (Continued)

\begin{tabular}{|c|c|c|c|}
\hline $\mathrm{PH}$ & Oxysterol_BP & $\begin{array}{l}\text { pleckstrin homology. Intracellular signaling/ } \\
\text { constituent of cytoskeleton }\end{array}$ & $\begin{array}{l}\text { Oxysterol binding protein. Steroid metabolic } \\
\text { process }\end{array}$ \\
\hline Ank & KH_I & Ankyrin repeat. Protein-protein interaction & K homology domain. RNA binding \\
\hline GON & TSP_I & $\begin{array}{l}\text { Proteinaceous extracellular matrix. Zinc ion } \\
\text { binding. Metalloendopeptidase activitiy. }\end{array}$ & Thrombospondin type I domain. Cell adhesion \\
\hline Thioredoxin & Dnal & Participates in redox reactions. & Heat shock protein binding \\
\hline Collagen & EMI & $\begin{array}{l}\text { Collagen triple helix repeat. Phosphate transport } \\
\text { process. Connective tissue structures. }\end{array}$ & EMI domain. Participates in multimerization \\
\hline HECT & $\mathrm{RCCl}$ & $\begin{array}{l}\text { HECT-domain (ubiquitin-transferase) Homologous } \\
\text { to the E6-AP Carboxyl terminus. Ubiquitin-protein } \\
\text { ligase; protein modification process. }\end{array}$ & $\begin{array}{l}\text { Regulator of chromose condensation. Acts as a } \\
\text { guanine-nucleotide dissociation simulator } \\
\text { (GDS) }\end{array}$ \\
\hline
\end{tabular}

predominant event, and types of domains \& molecular processes being most affected) from the analysis of Pfam or PRINTS have been supporting and complementing each other.

\section{Orphan protein isoforms?}

Tress et al [15] find little evidence as to whether a majority of protein isoforms, as identified in the ENCODE pilot project [44], have a role as functional proteins; they find substantial alterations in the 3-dimensional structures of as high as 49 of the 85 protein isoforms. It has been reported that there can be large conformational changes among protein isoforms in $67 \%$ instances of alternatively spliced genes [6]. Talavera et al [45] find that alternative splicing affects protein sequence and structure in a more drastic way as compared with other similar events (such as gene duplication \& divergence) that bring about diversity in proteins. Takeda et al [39] find that in 20\% instances of alternatively spliced human genes, the protein products lacked annotation for protein motifs. Further, it is known that pipelines such as ASD use EST/mRNA sequences from a variety of clones/CDNA libraries that are derived from either healthy or diseased or even pooled tissues; and curated data sets contain transcript/protein isoforms that are expressed in diseased states of the cell; thus it is possible that some of the protein isoforms are indeed expressed in diseased states and hence may lack any function.

We set out to identify such the set of protein isoforms that we call as 'orphan' isoforms; this term refers to situations where one or more (but not all) of the protein isoforms from a gene lack any annotation for either Pfam domains or PRINTS fingerprints. As mentioned earlier, examination of the protein isoforms led to four sets with varying degrees of annotation for Pfam/PRINTS signatures; of these, the Sets B-D may contain potential orphan isoforms. However, we consider only the Set D for the reason that it includes only those genes for which two or more isoforms could be annotated and decipherable changes in signatures could be seen among the isoforms. Certain details on the nature of observed orphan protein isoforms are as discussed below:

\section{(i) Length distributions of orphan isoforms}

Set D for Vega data set contains a total of 18297 isoforms of which 2687 isoforms lack any annotation for either fingerprints or domains (the corresponding numbers for ASD data set are 11004 and 2628). We examined length distributions of protein isoforms and found that the average length of orphan isoforms is low at 128 amino acids (109 in the case of ASD data set) while the average length of annotated isoforms can be high at 449 amino acids (360 in the case of ASD) and that of human proteins in UniProt/SwissProt is 450 amino acids. The annotated isoforms peaked at around 125 amino acids; the distribution for the orphan isoforms was seen to be distinct from that of annotated isoforms, peaks earlier, and does not have the pronounced tail. The observed low value for the average length of orphan isoforms is in the order of typical lengths of single-domain proteins; domain lengths distribution usually peak at around 100 residues [46].

\section{(ii) Threshold criteria used to annotate for Pfam domains and PRINTS fingerprints?}

We have used a threshold for E-value as $\leq 10^{-5}$ for accepting the annotation for Pfam domains and PRINTS fingerprints (see the section on Methods). Relaxing the requirement on E-value from $10^{-5}$ to $10^{-4}$, to $10^{-3}$, and to 1 reduces the count of orphan isoforms seen in Vega data set by only $6 \%, 9 \%$ and $12 \%$, respectively (in the case of ASD data set, there is virtually no reduction). Thus it is possible to say that the observation of orphan isoforms is not due to threshold criteria used to annotate for domains and fingerprints.

\section{(iii) Quality of underlying splice patterns}

The ASD pipeline uses transcript (EST/mRNA) sequences to decipher splice patterns. We find that splice patterns of at least $37 \%$ of orphan isoforms are supported by 2 or more transcript sequences, and up to $44 \%$ are supported by mRNA sequences; upon considering only those orphan isoforms of length $>=125$ amino acid residues (the length at which the distribution of annotated protein isoforms was seen to peak), these values increase to $48 \%$ and $60 \%$, respectively. 
Table 5: Pfam domains and the undergoing events - Gene \& events distribution $\$$

\begin{tabular}{|c|c|c|c|c|c|}
\hline \multirow[b]{2}{*}{ Pfam domain } & \multirow[b]{2}{*}{$\begin{array}{l}\text { No. of Genes that encode } \\
\text { the domain (in how many of } \\
\text { these genes, the domain } \\
\text { undergoes change) }\end{array}$} & \multicolumn{2}{|c|}{$\begin{array}{l}\text { Percent fraction of genes that show } \\
\text { the following events with the domain. }\end{array}$} & \multicolumn{2}{|c|}{$\begin{array}{l}\text { Percent fraction of events as per } \\
\text { the following types with the domain }\end{array}$} \\
\hline & & $\begin{array}{l}\text { insertion/deletion } \\
\text { Gene-\% }\end{array}$ & $\begin{array}{l}\text { Truncation } \\
\text { Gene-\% }\end{array}$ & $\begin{array}{l}\text { insertion/deletion } \\
\text { Event-\% }\end{array}$ & $\begin{array}{l}\text { Truncation } \\
\text { Event-\% }\end{array}$ \\
\hline \multirow[t]{2}{*}{ Pkinase } & 149 (139) & $29 \%$ & $77 \%$ & $27 \%$ & $72 \%$ \\
\hline & $48(4)$ & $2 \%$ & $6 \%$ & $25 \%$ & $75 \%$ \\
\hline \multirow[t]{2}{*}{$\mathrm{zf}-\mathrm{C} 2 \mathrm{H} 2$} & $138(106)$ & $75 \%$ & $1 \%$ & $98 \%$ & $1 \%$ \\
\hline & $127(61)$ & $48 \%$ & $0 \%$ & $100 \%$ & $0 \%$ \\
\hline \multirow[t]{2}{*}{$\mathrm{Cl}$-set } & $108(86)$ & $37 \%$ & $43 \%$ & $46 \%$ & $53 \%$ \\
\hline & $2(1)$ & $50 \%$ & $0 \%$ & $100 \%$ & $0 \%$ \\
\hline \multirow[t]{2}{*}{$\mathrm{PH}$} & $94(73)$ & $62 \%$ & $25 \%$ & $71 \%$ & $28 \%$ \\
\hline & $50(24)$ & $44 \%$ & $12 \%$ & $78 \%$ & $21 \%$ \\
\hline \multirow[t]{2}{*}{ Ank } & $67(55)$ & $80 \%$ & $7 \%$ & $91 \%$ & $8 \%$ \\
\hline & $72(25)$ & $34 \%$ & $5 \%$ & $86 \%$ & $13 \%$ \\
\hline \multirow[t]{2}{*}{ ig } & $62(52)$ & $82 \%$ & $8 \%$ & $91 \%$ & $8 \%$ \\
\hline & Not seen in ASD & & & & \\
\hline \multirow[t]{2}{*}{ fn3 } & $59(49)$ & $77 \%$ & $30 \%$ & $71 \%$ & $28 \%$ \\
\hline & $21(6)$ & $28 \%$ & $4 \%$ & $85 \%$ & $14 \%$ \\
\hline \multirow[t]{2}{*}{ SPRY } & $59(48)$ & $77 \%$ & $5 \%$ & $93 \%$ & $6 \%$ \\
\hline & $4(3)$ & $75 \%$ & $0 \%$ & $100 \%$ & $0 \%$ \\
\hline \multirow[t]{2}{*}{ Trypsin } & $47(47)$ & $42 \%$ & $68 \%$ & $38 \%$ & $61 \%$ \\
\hline & $36(29)$ & $30 \%$ & $55 \%$ & $35 \%$ & $64 \%$ \\
\hline \multirow[t]{2}{*}{ PDZ } & $65(46)$ & $66 \%$ & $27 \%$ & $70 \%$ & $29 \%$ \\
\hline & $42(20)$ & $42 \%$ & $11 \%$ & $78 \%$ & $21 \%$ \\
\hline \multirow[t]{2}{*}{$\mathrm{zf}-\mathrm{C} 3 \mathrm{HC} 4$} & $72(46)$ & $61 \%$ & $4 \%$ & $93 \%$ & $6 \%$ \\
\hline & $14(7)$ & $50 \%$ & $0 \%$ & $100 \%$ & $0 \%$ \\
\hline \multirow[t]{2}{*}{ Collagen } & $51(45)$ & $88 \%$ & $37 \%$ & $70 \%$ & $29 \%$ \\
\hline & $12(8)$ & $66 \%$ & $0 \%$ & $100 \%$ & $0 \%$ \\
\hline \multirow[t]{2}{*}{ KRAB } & $90(43)$ & $46 \%$ & $2 \%$ & $95 \%$ & $4 \%$ \\
\hline & $69(34)$ & $49 \%$ & $1 \%$ & $97 \%$ & $2 \%$ \\
\hline \multirow[t]{2}{*}{ SH3_I } & $77(43)$ & $51 \%$ & $9 \%$ & $85 \%$ & $14 \%$ \\
\hline & $45(4)$ & $8 \%$ & $0 \%$ & $100 \%$ & $0 \%$ \\
\hline \multirow[t]{2}{*}{ WD40 } & $48(43)$ & $83 \%$ & $18 \%$ & $81 \%$ & $18 \%$ \\
\hline & $90(35)$ & $38 \%$ & $2 \%$ & $94 \%$ & $5 \%$ \\
\hline Sushi & $40(40)$ & $97 \%$ & $27 \%$ & $78 \%$ & $22 \%$ \\
\hline & $23(17)$ & $73 \%$ & $4 \%$ & $\mathbf{9 4 \%}$ & $5 \%$ \\
\hline EGF & $48(40)$ & $83 \%$ & $8 \%$ & $90 \%$ & $9 \%$ \\
\hline & $27(5)$ & $18 \%$ & $0 \%$ & $100 \%$ & $0 \%$ \\
\hline Ras & $41(39)$ & $4 \%$ & $92 \%$ & $5 \%$ & $95 \%$ \\
\hline & Not present in ASD & & & & \\
\hline Helicase_C & $51(38)$ & $62 \%$ & $35 \%$ & $64 \%$ & $36 \%$ \\
\hline & $27(13)$ & $44 \%$ & $11 \%$ & $80 \%$ & $20 \%$ \\
\hline RRM_I & $43(38)$ & $72 \%$ & $46 \%$ & $60 \%$ & $39 \%$ \\
\hline & $45(24)$ & $46 \%$ & $20 \%$ & $70 \%$ & $30 \%$ \\
\hline MHC_I & $50(35)$ & $12 \%$ & $70 \%$ & $14 \%$ & $85 \%$ \\
\hline & $5(3)$ & $0 \%$ & $60 \%$ & $0 \%$ & $100 \%$ \\
\hline$A B C$ tran & $36(33)$ & $50 \%$ & $80 \%$ & $38 \%$ & $61 \%$ \\
\hline & $18(13)$ & $38 \%$ & $61 \%$ & $38 \%$ & $61 \%$ \\
\hline zf-B_box & 47 (33) & $46 \%$ & $25 \%$ & $64 \%$ & $35 \%$ \\
\hline & $14(3)$ & $21 \%$ & $0 \%$ & $100 \%$ & $0 \%$ \\
\hline $\mathrm{C} 2$ & $44(32)$ & $61 \%$ & $36 \%$ & $62 \%$ & $37 \%$ \\
\hline & $30(17)$ & $53 \%$ & $10 \%$ & $84 \%$ & $15 \%$ \\
\hline LIM & $23(22)$ & $82 \%$ & $39 \%$ & $67 \%$ & $32 \%$ \\
\hline & $27(20)$ & $74 \%$ & $14 \%$ & $83 \%$ & $16 \%$ \\
\hline Mito_carr & $23(22)$ & $91 \%$ & $73 \%$ & $55 \%$ & $44 \%$ \\
\hline & $22(19)$ & $86 \%$ & $59 \%$ & $59 \%$ & $40 \%$ \\
\hline
\end{tabular}

\$, Line I gives the values from Vega data set and Line 2 gives the values from ASD data set.

Domains that particularly undergo insertion/deletion events in a higher fraction of genes (containing the specific domain) as compared to truncation events are: $\mathrm{zf}-\mathrm{C} 2 \mathrm{H} 2$, PH, Ank, SPRY, KRAB, WD40, Sushi, and EGF. Domains that undergo truncation events in higher fraction of genes (containing the specific domain) as compared to insertion/deletion events: Trypsin, Ras, MHC_I, and ABC_trans. Since Swap events were seen in few instances, they are not considered in deriving this table 
(iv) Transcripts corresponding to orphan isoforms and nonsensemediated decay (NMD)

It is known that certain alternative splice events lead to transcripts that are targeted for nonsense-mediated decay [36-38]. Upon examination of the ASD splice patterns corresponding to the orphan isoforms for susceptibility to nonsense-mediated decay, it is seen that only in 5.5\% instances of orphan isoforms, the transcripts are putative candidates for nonsense-mediated decay. This extent is much lower than the reported estimates (namely that one in five to one in three alternatively spliced transcripts are susceptible to NMD [36-38]). Instances of transcripts susceptible to NMD can be seen even with annotated protein isoforms - the corresponding values in the case of annotated protein isoforms are $7.9 \%$ - suggesting that the observed orphan isoforms are particularly not artifacts due to lack in validating transcript data for NMD. It is appropriate to recollect from literature that NMD machinery rarely down regulates the expression of a transcript completely; $10-30 \%$ of transcripts containing premature stop codons survive (NMD-escape) and may lead to production of physiologically relevant levels of truncated protein products $[47,48]$.

(v) The orphan protein isoforms probably lack any known function The transcript sequences (confirming the isoform splice patterns in the ASD pipeline) are derived from clone/ cDNA libraries with the tissue state as normal or disease disorder or as pooled/mixed; e.g. upon querying the ASD database for the count of genes with transcripts seen expressed in normal versus neoplasia cDNA libraries, it is seen that (i) for 10477 genes, at least one of the expressed transcripts is from cDNA libraries with pathological state as normal; and (ii) in roughly equal number of genes at 9590, at least one of the expressed transcripts is from cDNA libraries with neoplasia as pathological state. Aberrantly expressed splice patterns are seen in diseased cells, such as cancer [49]; the number of aberrant splicing processes causing human disease is growing exponentially (see [50] for a review). Thus, it is quite possible that the orphan protein isoforms are seen probably as results of aberrant splicing in disease states of the cell and hence they lack annotation for signatures. It is important to note that the signatures seen in the constitutive protein (and in some of the encoded isoforms) are totally lost in orphan isoforms and hence the functions associated with the constitutive protein are lost in the orphan isoforms. Further, it is safe to say that Pfam and PRINTS are probably comprehensive enough to report signatures of 'known' functions. Hence we can say that the orphan isoforms lack any 'known'

function.

\section{(vi) Estimates for orphan protein isoforms}

A wild estimate is one that is based on unannotated protein isoforms of all lengths. Vega data set: Of 18297 iso- forms (from 4673 genes), 2687 isoforms (from 1385 genes) are orphans; ASD data set: of 11004 isoforms (from 2678 genes), 2628 isoforms (from 2628 genes) are orphans. Such a wild estimate is: From Vega data set: (a) one in every 3.4 genes can express an orphan protein that lacks any "known" function, and (b) One in every 6.8 alternative splice events can result in transcript isoform that encodes a protein lacking any "known" function; From ASD data set: one in every 1.02 genes and one in every 4.2 isoforms. A conservative estimate can be obtained by ignoring short isoforms of length $<125$ residues - in Vega data set, of 13591 isoforms (from 4248 genes) of lengths $>=125$ amino acid residues, 722 isoforms (from 477 genes) are orphans. The conservative estimate as seen in Vega data set is: one in 8.9 genes can be seen to lead to a protein isoform of no "known" function; and one in 18 protein isoforms can be such an orphan isoform; the corresponding numbers as seen in ASD data set are: one in 4.9 genes and one in 9.8 isoforms. We wish to emphasize that these estimates are subject to corrections for regulations, such as NMD, RNA silencing at transcript level and decay by cellular degradation machinery at the protein level; however, we believe that such corrections are probably taken care by the elimination of protein isoforms of shorter lengths in deriving the conserved estimate.

\section{Concerns \& Caveats}

Certain concerns, that may arise due to the methodologies $\&$ the nature of the data resources are discussed below.

\section{(i) Repeats}

Annotation of a fair number of isoforms comprises repeats of a single or multiple signatures. Delineating events from such annotation is difficult and can lead to ambiguous results. In such instances, we avoided delineation of events.

\section{(ii) E-value thresholds}

There can be instances where the E-values are close to the chosen threshold but still not good enough to accept the annotated domain/fingerprints and such instances can lead to identification of further events.

\section{(iii) Underlying splice events}

One may raise a concern that the events of domain deletion, swapping and reshuffling are unlikely produced by simple exon skipping or 5' and 3' splice events. Cassette exon events (and others such as alternating exon, and intron retention) can often be complex exon events - i.e. they often occur in association with extension/truncation of either one or both the flanking exons. It has been documented in ASD web pages, that 27\% instances of the 18815 inferred cassette exons occur in complex form (see http://www.ebi.ac.uk/asd/altsplice/humrel3-dist- 
data.html). Of the reported 18815 cassette exon events, 13799 events occur only as simple cassette exons (SCE); 1418 events occur only as complex cassette exons (CCE); and 3589 occur in both the SCE and CCE forms. Cassette events involving successive multiple exons have also been reported. Intron retention events are not seen as very rare. Further, it is to be noted that an entire region of a domain does not have to be necessarily removed; deletion of crucial regions is enough to make the E-value of Pfam annotation not acceptable. An interesting aspect to consider for further studies relates to mechanistic connections between alterations (insertion/deletion, truncation, alternating, and reshuffle) of domains/fingerprints among protein isoforms to the types (exon extension/truncation, intron retention, cassette exon, alternating exon events) and extents ('simple' or 'complex' as defined in the ASD database) of splice events. We find interesting examples in our data set where alterations of protein signatures are not effected by variation in exons that code for such signatures but rather by variations in upstream exons that shift the reading frame; such an observation has been seen as prevalent in literature [42].

(iv) Concerns due to EST sequences in the ASD data set The isoform splice patterns as inferred by the ASD pipeline are delineated from gene-transcript alignments; since these transcripts (cDNA/EST/mRNA) are from different sources and conditions, it leads to a concern that some of the inferred full-length transcripts are chimeric isoforms. However, this is not the case with the ASD pipeline for the following reasons: Portions of a chimeric transcript are generally from different chromosomes or from distant regions of the same chromosome. Chimeric transcripts usually pose problems when one assembles transcripts to derive gene structures or full-length transcripts. The ASD pipeline does not cluster transcripts to assemble fulllength transcripts; the pipeline maps transcripts onto 'known' genes from Ensembl [51] and delineate the unique splice patterns. The methods adopted in the ASD pipeline take care that chimeric EST's are not considered some of the relevant filter criteria (see [52] and the ASD online documents at http://www.ebi.ac.uk/asd/documen tation.html for more details) used are: (a) gene-transcript alignments that involve transcript sequences matching more than one gene are removed; (b) if a region of a transcript sequence matches more than one region of a gene, then the transcript sequence is removed; (c) transcripts that maps only to the flanking regions of a gene (considered is the Ensembl gene plus a region of 3000 bases flanking the gene) are ignored; matches in gene-transcript alignments of length less than a threshold are ignored; (d) transcript-gene alignments that contain only a single match on the gene are removed; and (e) gene-transcript alignments that show gap between matches on the transcript sequences are removed. (v) Concerns due to derivation of protein sequence in the ASD data set

EST libraries have a $5^{\prime}$ bias (i.e. a fraction of cDNA/EST sequences is truncated at the $5^{\prime}$ end) and thus there can be possibilities that some of the identified splice patterns in computationally predicted data set are truncated at the $5^{\prime}$ end. Identification of coding sequence as the longest open reading frame (ORF) from an ATG codon might provide a truncated protein isoform sequence. However, for reasons stated below, we believe that this concern has been addressed to a large extent, if not completely, by the methods of the ASD pipeline. It is not that the longest ORF from any ATG codon is considered; the context-sequence of such an ATG should score higher than a threshold value of the Kozak's ATG-context score [29]. The nucleotide sequences around the translation-initiation ATG codon is supposed to be distinctly different from those around the non-initiation ATG codons. In the ASD pipeline, known human mRNA sequences with experimentally determined translation-initiation codon were collected and used to define the threshold for the context score of initiation ATG codons. Use of this step (along with others such as match to a reference protein and requirement of a minimal length) is expected to eliminate truncated peptide sequences that start on any ATG on the splice pattern sequence.

\section{Use of Vega versus ASD databases for data on protein isoforms}

In this work, we considered two distinct data types - one comprising manually curated protein isoforms from Vega and the other comprising protein isoforms as delineated from EST resources by the ASD computational pipeline. The estimates for orphan isoforms was seen much higher with ASD data set - a possible reason for this is that the ASD pipeline uses EST/mRNA transcript sequences, and as briefed earlier, a majority of the EST libraries are constructed from diseased tissues; and hence some of the observed protein isoforms are expressed only in diseased state of the cell and they probably lack any function. However, in general, both the data resources lead to similar results in terms of signatures that often undergo changes among protein isoforms. This observation builds a case for use of such computationally predicted databases that are, in general, are larger in size than the manually curated databases.

\section{SpliVaP DATABASE}

\section{Contents of the database}

The presented work led to developing a database that holds data on protein isoforms with observed changes in signatures and domains. The main tables of the database are genes, protein isoforms, annotated domains \& signatures, and the changes among the isoforms. Presented in the database are the genes and isoforms from Set D (see 


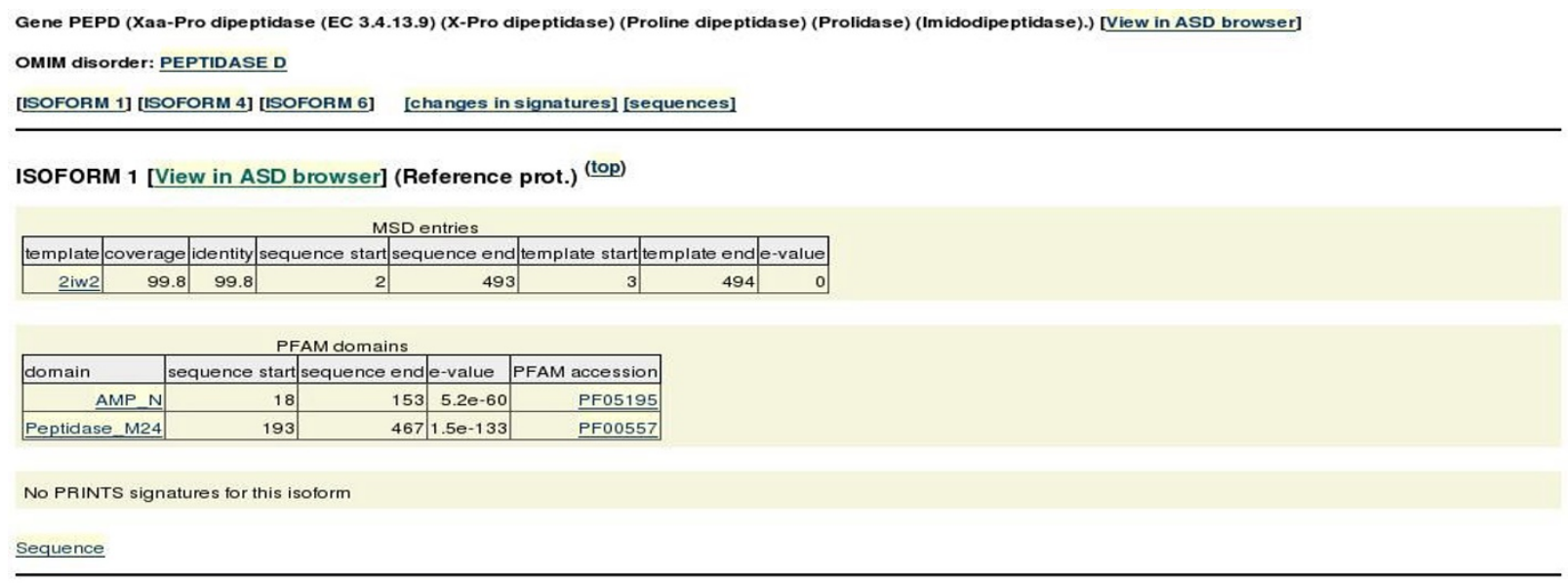

ISOFORM 4 [View in ASD browser] (top)
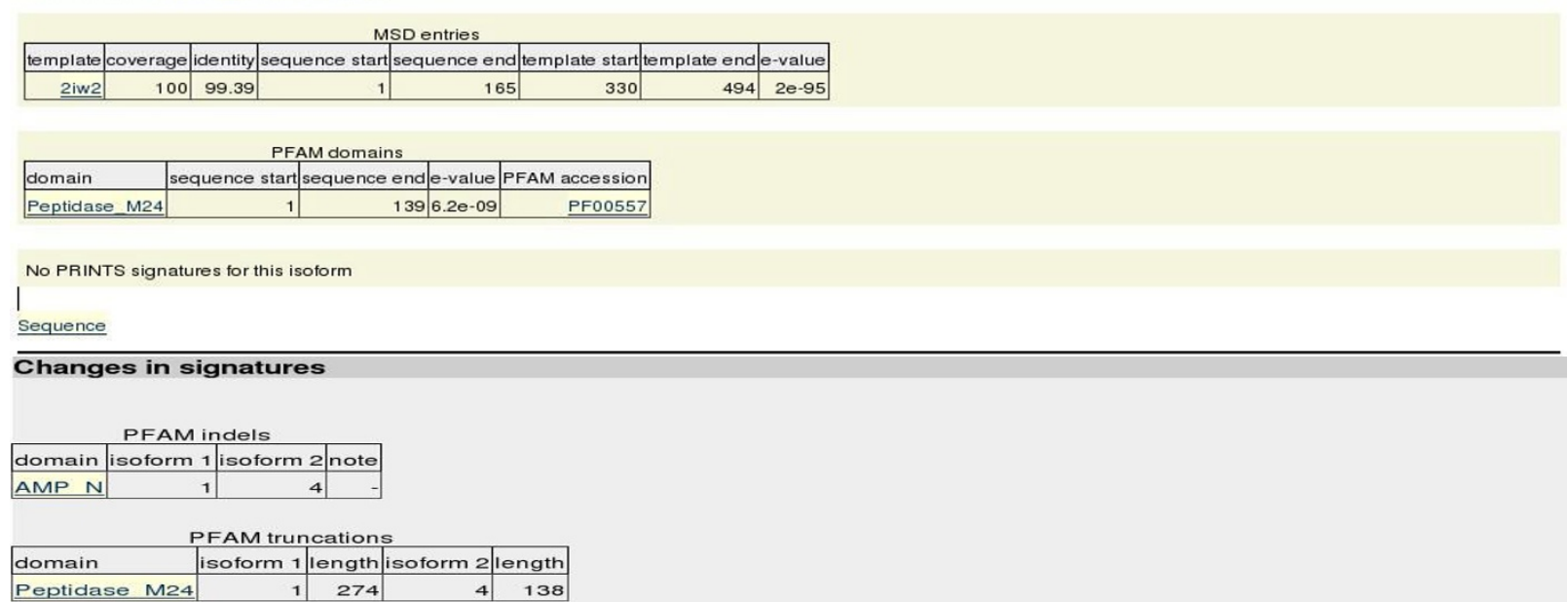

\section{Figure 3}

Illustration of a typical result page from the web access of SpliVaP database. Reported is the data on protein isoforms from PEPD gene. Reported changes in Pfam domains between two isoforms SPI and SP4 (which are hyperlinked to splice patterns in ASD database) are an insertion/deletion and a truncation. Associations to a template structure entry in MSD, and to a related entry of genetic disorder in OMIM are shown and are hyperlinked.

the section on "Varying degrees of annotation of protein isoforms for Pfam/PRINTS signatures"). The current release 1 of the database holds (i) 4673 Vega genes with 19,827 protein isoform sequences that are annotated with 727 distinct fingerprint signatures (of which 637 could be associated with at least one GO term) and 2057 distinct Pfam domain signatures (of which 1242 could be associated with at least one GO term); and (ii) 2678 ASD genes with 11,004 protein isoform sequences that are annotated with 590 distinct fingerprint signatures (of which 528 could be associated with at least one GO term) and 1592 distinct Pfam domain signatures (of which 1012 could be associated with at least one GO term).

\section{Examination of the $\mathrm{GO}$ terms}

Examining the GO terms (associated with the mapped fingerprints and Pfam domains in our data set) reveal the following as the oft-affected molecular functions: binding activity: (nucleic acid, protein, carbohydrate, lipid, cofactor, chromatin, steroid, nucleotide, nucleoside, selenium, oxygen); catalytic activity: (transferase, ligase, isomerase, oxidoreductase, deaminase, integrase, helicase, hydrolase, lyase, small protein activating enzyme); transcription regulator activity: (transcription activator, transcription repressor, transcription initiation factor, transcription factor, transcription cofactor, RNA polII transcription factor, two-component response regulator); structural molecule activity: (structural constituent of nuclear pore, vitelline membrane, ribosome, myelin sheath, extracellular 
matrix); transporter activity: (drug, nucleocytoplasmic); motor; and antioxidant activities.

\section{Association with disease disorders}

We made associations to disease disorders by using information from OMIM database. The association seen in our data sets between splice-mediated changes and disease genes (Event Type: No. Of genes) are as follows: FOR VEGA: Pfam domain truncation: 2281 disease genes; Pfam domain insertion/deletion: 1406 disease genes; Pfam domain swap: 28 disease genes; PRINTS Class_A insertion/deletion: 159 disease genes; PRINTS class_B insertion/deletion: 579 disease genes; PRINTS class_C insertion/deletion: 65 disease genes; PRINTS class_D insertion/deletion: 103 disease genes; and PRINTS swap: 4 disease genes. FOR ASD: Pfam domain truncation: 1319 disease genes; Pfam domain insertion/deletion: 806 disease genes; Pfam domain swap: 3 disease genes; PRINTS Class_A insertion/deletion: 145 disease genes; PRINTS class_B insertion/deletion: 516 disease genes; PRINTS class_C insertion/deletion: 90 disease genes; PRINTS class_D insertion/deletion: 141 disease genes; and PRINTS swap: 1 disease genes.

\section{Association with structural templates}

Search for associations between protein isoform sequences in our data set and data entries in Macromolecular Structure Database resulted in a set of 836 Vega genes (538 ASD genes). In each such gene, at least one protein isoform sequence can be associated with an MSD entry. In 699 of the 836 Vega genes (247 of the 538 ASD genes), more than one isoform sequence could be associated with structural data; except for few cases, the template entry from MSD was same for the multiple isoform sequences from a gene. Examination of these data indicated that such isoform sequences (with associations to MSD entries) are often results of protein shortenings (truncations) at either or both the $\mathrm{N}$ - and C-terminal ends. The data of such associations and indications of target structure data are useful to those who want to do homology modelling for studying structural effects of alternative splicing.

The data can be accessed via a web query interface available from our web site at http://www.bioinformat ica.crs4.org/tools/dbs/splivap/. The interface allows the users to query the database through (i) gene names, GO terms, and keywords (on diseases, protein signatures \& protein descriptions); (ii) associations with MSD entry and OMIM entry identifiers; (iii) types of changes (splicemediated changes in PRINTS fingerprints and in Pfam domains); and (iv) against specific classes of PRINTS and Pfam definitions. Cross-references have been made to UniProt [28] for detailed protein information, Ensembl [51] for detailed genome annotation information, ASD for underlying transcript patterns, MSD for structural data \& visualizations, and OMIM for information on genetic disorders. The interface provides an option to restrict the query to only the genes and isoforms (from curated data set) that are common between SpliVaP and Vega data sets.

Figure 3 shows an exemplary result page. Reported is the data on protein isoforms from PEPD gene. Changes (insertion/deletion and truncation of Pfam domains) are seen between two isoforms SP1 and SP4. The isoforms are hyperlinked to ASD database to show the underlying splice patterns. Association to a template structure entry in MSD, and to a related entry of genetic disorder in OMIM is shown and is hyperlinked.

\section{Utility of the SpliVaP Database}

Several databases have been published in recent years to provide access to alternative splicing data. Some of the notable ones are HOLLYWOOD [53], ASAP II [54], HDBAS [55], Ecgene [56], FAST-DB[57], ASTALAVISTA [58], ATD/ASD [27,59], ASPicDB [60]. Most of these databases (ASD, ASAP II, ECgene and H-DBAS) deal mainly with the collection of transcript isoforms at the nucleotide level that are then annotated with functional features such as InterPro [61] patterns, tissue specificity and literature data describing the specific isoforms. Further, databases such as Ensembl and SwissProt report splice-mediated protein variants and annotate the protein sequences for structural and functional features. Though many of these databases can be queried through features of gene and splice variants to obtain the underlying splice patterns and protein coding features, they generally do not allow the users to query for splice variants through specific changes in the composition of specific signatures (such as Pfam domains and PRINTS fingerprints) - the ability to access splice-mediated protein isoforms through changes in protein signatures (such as domain truncation or insertion/deletion) as well as the ability to obtain pre-processed information reporting changes in functional motifs among protein isoforms is missing. The SpliVaP database that we present to the community fills this gap. Thus, SpliVaP is useful for researchers in splicing community, in particular to those who are interested in studying the functional effects on protein variants. In addition, it is useful to researchers working in disease biology to access disease-associated genes that express, through alternative and aberrant splicing, proteins with altered functions the database contains 3014 Vega genes that are associated with 2808 unique OMIM entries (ASD: 2038 genes, 2496 distinct OMIM entries). The presented association of protein isoforms with entries in structural database provides structure templates that the users can utilize for structural studies on splice-mediated changes in protein sequences. Association of protein isoform sequences with structural 
data entries from MSD could be made in the case of 836 Vega genes and 538 ASD genes.

\section{Conclusion}

The work presented here considers protein variants that are (i) extracted from manually curated database of Vega, and (ii) derived by ASD computational pipeline from transcript sequences (EST/mRNA/cDNA), and reports splice-mediated changes in protein isoforms.

Protein molecular functions that are often affected by alternative splicing in our data sets are: binding activity, catalytic activity, transcription regulator activity, structural molecule activity, transporter activity, motor, and antioxidant activities; major processes that are affected are regulation of transcription, signal transduction, and proteinprotein interaction. This observation gains support from previous studies (that use computationally predicted protein isoforms $[6,8,62]$ or that use protein isoforms from curated databases $[37,63])$ - see $[5,9]$ for excellent reviews). A diverse range of changes are seen among protein isoforms, from removal of a complete domain/fingerprint to truncation of a domain or removal of a component motif of a fingerprint. Signatures can be seen alternated between two protein isoforms, though at a lower frequency than other events. The presented data suggests that alternative splicing can act (i) to make proteins lose completely functionalities of specific regions or gain new/additional functionalities (through events such as insertion/deletion of fingerprints/domains), or (ii) to act as a modulator of function (through events such as truncations of domains \& fingerprints, and swap between those of same classifications), or (iii) to change the protein function (through events as swap between signatures of different classifications.

The following are novel aspects: (i) Swapping of domains/ signatures seems to occur often between those of same family (Structural/Functional) classifications. (ii) Pfam domains can be seen in varying lengths among protein isoforms, and fingerprints can be seen with varying number of constituent motifs among protein isoforms; since such a variation is seen in a large number of genes and protein isoforms, it could be a general mechanism to modulate the protein function among isoforms. The observation of truncation events gain support from studies by others - e.g. Kriventseva et al [63] find that disruption of sequence forming a domain (similar to domain truncations) is seen in considerable fraction (up to 28\%) of splice variants. (iii) We speculate that some of the splice-mediated protein isoform products may lack any "known" function and such proteins isoforms are probably expressed in disease states of tissues; a conservative estimate using data from the manually curated Vega is that one in 9 genes can lead to a protein isoform of no "known" function; and one in 18 expressed protein isoforms can be such an orphan isoform; the corresponding numbers as seen with computationally predicted ASD data set are: one in 5 genes and one in 10 isoforms.

The resultant data of protein isoforms that are annotated for splice-mediated changes is presented to the community as SpliVaP database through web query interfaces. Data on protein variants are cross-referenced to underlying transcript patterns, genome context, genetic disorders, and structural data. It is our intention to update the database regularly and expand in functionalities. A particularly important expansion in functionalities is to develop an automated procedure for extracting structural information of alternatively spliced peptide regions and to include in the database.

\section{Availability and requirements}

Release 1 of the SpliVaP data, presented in this manuscript, is available from http://www.bioinformat ica.crs4.org/tools/dbs/splivap/. Enquiries on accessing the data can be mailed to splivap@crs4.it.

\section{Abbreviations}

Vega: Vertebrate genome annotation database; SpliVaP: Splice-mediated Variants of Proteins; EST: expressed sequence tag; mRNA: messenger RNA; pre-mRNA: precursor mRNA; BLAST: Basic Local Alignment Search Tool; ASD: Alternative Splicing Database; MSD: Macromolecular Structure Database; PDB: Protein Data Bank; PRINTS: Database of protein motif fingerprints; Pfam: Database of Protein Family Domain signatures; OMIM: Online Mendelian Inheritance in Man - a database of human genes and genetic disorders; GO - Gene Ontology that provides a controlled vocabulary to describe gene and gene product attributes; UniProt: Universal Protein Resource; SwissProt: Protein sequence database; InterProScan: It is a tool that scans a given protein sequence against protein signatures; Ensembl: A system that maintains automatic annotation of genomes.

\section{Authors' contributions}

MF carried out the fingerprint analysis, part of Pfam analysis, NMD analysis, association with OMIM \& other data resources, and building the database \& interfaces. MO carried out the Pfam analysis. TAT is responsible for formulating and directing the research analysis and the development of the SpliVaP pipeline \& database. TAT developed the manuscript with contributions coming from MF and MO. 


\section{Additional material}

\section{Additional file 1}

PRINTS fingerprints frequently participating in insertion/deletion events. The top 10 frequently observed fingerprints that undergo insertion/deletion event (with either the whole fingerprint or some of the constituent motifs being affected) among protein isoforms.

Click here for file

[http://www.biomedcentral.com/content/supplementary/14712164-9-453-S1.pdf]

\section{Additional file 2}

Swap, and reshuffle events involving Pfam domains and PRINTS fingerprints. The observed swap and reshuffle events (along with the patterns of the isoform pairs) involving Pfam domains are listed.

Click here for file

[http://www.biomedcentral.com/content/supplementary/14712164-9-453-S2.pdf]

\section{Acknowledgements}

The authors thank Professor Anna Tramontano for her support and encouragement. Ricardo Medda is acknowledged for his help with accessing and mining data from OMIM entries.

\section{References}

I. Stetefeld J, Ruegg MA: Structural and functional diversity generated by alternative mRNA splicing. Trends Biochem Sci 2005, 30:515-521.

2. Lander ES, Linton LM, Birren B, Nusbaum C, Zody MC, Baldwin J, Devon K, Dewar K, Doyle M, FitzHugh W, Funke R, Gage D, Harris K, Heaford A, Howland J, Kann L, Lehoczky J, LeVine R, McEwan P, McKernan K, Meldrim J, Mesirov JP, Miranda C, Morris W, Naylor J, Raymond C, Rosetti M, Santos R, Sheridan A, Sougnez C, StangeThomann N, Stojanovic N, Subramanian A, Wyman D, Rogers J, Sulston J, Ainscough R, Beck S, Bentley D, Burton J, Clee C, Carter N, Coulson A, Deadman R, Deloukas P, Dunham A, Dunham I, Durbin R, French L, Grafham D, Gregory S, Hubbard T, Humphray S, Hunt A, Jones M, Lloyd C, McMurray A, Matthews L, Mercer S, Milne S, Mullikin JC, Mungall A, Plumb R, Ross M, Shownkeen R, Sims S, Waterston RH, Wilson RK, Hillier LW, McPherson JD, Marra MA, Mardis ER, Fulton LA, Chinwalla AT, Pepin KH, Gish WR, Chissoe SL, Wendl MC, Delehaunty KD, Miner TL, Delehaunty A, Kramer JB, Cook LL, Fulton RS, Johnson DL, Minx PJ, Clifton SW, Hawkins T, Branscomb E, Predki P, Richardson P, Wenning S, Slezak T, Doggett $\mathrm{N}$, Cheng JF, Olsen A, Lucas S, Elkin C, Uberbacher E, Frazier M, Gibbs RA, Muzny DM, Scherer SE, Bouck JB, Sodergren EJ, Worley KC, Rives CM, Gorrell JH, Metzker ML, Naylor SL, Kucherlapati RS, Nelson DL, Weinstock GM, Sakaki Y, Fujiyama A, Hattori M, Yada T, Toyoda A, Itoh T, Kawagoe C, Watanabe H, Totoki Y, Taylor T, Weissenbach J, Heilig R, Saurin W, Artiguenave F, Brottier P, Bruls T, Pelletier E, Robert C, Wincker P, Smith DR, Doucette-Stamm L Rubenfield M, Weinstock K, Lee HM, Dubois J, Rosenthal A, Platzer M, Nyakatura G, Taudien S, Rump A, Yang H, Yu J, Wang J, Huang G, Gu J, Hood L, Rowen L, Madan A, Qin S, Davis RW, Federspiel NA, Abola AP, Proctor MJ, Myers RM, Schmutz J, Dickson M, Grimwood J, Cox DR, Olson MV, Kaul R, Raymond C, Shimizu N, Kawasaki K, Minoshima S, Evans GA, Athanasiou M, Schultz R, Roe BA, Chen F, Pan H, Ramser J, Lehrach H, Reinhardt R, McCombie WR, de la Bastide M, Dedhia N, Blöcker H, Hornischer K, Nordsiek G, Agarwala R, Aravind L, Bailey JA, Bateman A, Batzoglou S, Birney E, Bork P, Brown DG, Burge CB, Cerutti L, Chen HC, Church D, Clamp M. Copley RR, Doerks T, Eddy SR, Eichler EE, Furey TS, Galagan J, Gilbert JG, Harmon C, Hayashizaki Y, Haussler D, Hermjakob $H$, Hokamp K, Jang W, Johnson LS, Jones TA, Kasif S, Kaspryzk A Kennedy S, Kent W], Kitts P, Koonin EV, Korf I, Kulp D, Lancet D,
Lowe TM, McLysaght A, Mikkelsen T, Moran JV, Mulder N, Pollara VJ, Ponting CP, Schuler G, Schultz J, Slater G, Smit AF, Stupka E, Szustakowski J, Thierry-Mieg D, Thierry-Mieg J, Wagner L, Wallis J, Wheeler R, Williams A, Wolf YI, Wolfe KH, Yang SP, Yeh RF, Collins F, Guyer MS, Peterson J, Felsenfeld A, Wetterstrand KA, Patrinos A, Morgan MJ, de Jong P, Catanese J], Osoegawa K, Shizuya H, Choi S, Chen YJ, International Human Genome Sequencing Consortium: Initial sequencing and analysis of the human genome. Nature 200I, 409:860-92I.

3. Venter JC, Adams MD, Myers EW, Li PW, Mural RJ, Sutton GG, Smith HO, Yandell M, Evans CA, Holt RA, Gocayne JD, Amanatides P, Ballew RM, Huson DH, Wortman JR, Zhang Q, Kodira CD, Zheng XH, Chen L, Skupski M, Subramanian G, Thomas PD, Zhang J, Gabor Miklos GL, Nelson C, Broder S, Clark AG, Nadeau J, McKusick VA, Zinder N, Levine AJ, Roberts RJ, Simon M, Slayman C, Hunkapiller M, Bolanos R, Delcher A, Dew I, Fasulo D, Flanigan M, Florea L, Halpern A, Hannenhalli S, Kravitz S, Levy S, Mobarry C, Reinert K, Remington K, Abu-Threideh J, Beasley E, Biddick K, Bonazzi V, Brandon R, Cargill M, Chandramouliswaran I, Charlab R, Chaturvedi K, Deng Z, Di Francesco V, Dunn P, Eilbeck K, Evangelista C, Gabrielian AE, Gan W, Ge W, Gong F, Gu Z, Guan P, Heiman TJ, Higgins ME, Ji RR, Ke Z, Ketchum KA, Lai Z, Lei Y, Li Z, Li J, Liang Y, Lin X, Lu F, Merkulov GV, Milshina N, Moore HM, Naik AK, Narayan VA, Neelam B, Nusskern D, Rusch DB, Salzberg S, Shao W, Shue B, Sun J, Wang Z, Wang A, Wang $X$, Wang J, Wei M, Wides R, Xiao C, Yan C, Yao A, Ye J, Zhan M, Zhang W, Zhang H, Zhao Q, Zheng L, Zhong F, Zhong W, Zhu S, Zhao S, Gilbert D, Baumhueter S, Spier G, Carter C, Cravchik A, Woodage T, Ali F, An H, Awe A, Baldwin D, Baden H, Barnstead M, Barrow I, Beeson K, Busam D, Carver A, Center A, Cheng ML, Curry L, Danaher S, Davenport L, Desilets R, Dietz S, Dodson K, Doup L, Ferriera S, Garg N, Gluecksmann A, Hart B, Haynes J, Haynes C, Heiner C, Hladun S, Hostin D, Houck J, Howland T, lbegwam C, Johnson J, Kalush F, Kline L, Koduru S, Love A, Mann F, May D, McCawley S, Mclntosh T, McMullen I, Moy M, Moy L, Murphy B, Nelson K, Pfannkoch C, Pratts E, Puri V, Qureshi H, Reardon M, Rodriguez R, Rogers $Y H$, Romblad D, Ruhfel B, Scott R, Sitter C, Smallwood M, Stewart E, Strong R, Suh E, Thomas R, Tint NN, Tse S, Vech C, Wang G, Wetter J, Williams S, Williams M, Windsor S, WinnDeen E, Wolfe K, Zaveri J, Zaveri K, Abril JF, Guigó R, Campbell MJ, Sjolander KV, Karlak B, Kejariwal A, Mi H, Lazareva B, Hatton T, Narechania A, Diemer K, Muruganujan A, Guo N, Sato S, Bafna V, Istrail S, Lippert R, Schwartz R, Walenz B, Yooseph S, Allen D, Basu A, Baxendale J, Blick L, Caminha M, Carnes-Stine J, Caulk P, Chiang YH, Coyne M, Dahlke C, Mays A, Dombroski M, Donnelly M, Ely D, Esparham S, Fosler C, Gire H, Glanowski S, Glasser K, Glodek A, Gorokhov M, Graham K, Gropman B, Harris M, Heil J, Henderson S, Hoover J, Jennings D, Jordan C, Jordan J, Kasha J, Kagan L, Kraft C, Levitsky A, Lewis M, Liu X, Lopez J, Ma D, Majoros W, McDaniel J, Murphy S, Newman M, Nguyen T, Nguyen N, Nodell M, Pan S, Peck J, Peterson M, Rowe W, Sanders R, Scott J, Simpson M, Smith T, Sprague A, Stockwell T, Turner R, Venter E, Wang M, Wen M, Wu $D$, Wu $M, X i a A$, Zandieh $A$, Zhu $X$ : The sequence of the human genome. Science 200I, 29 I: I304-5I.

4. Mount SM: Genomic sequence, splicing, and gene annotation. Am J Hum Genet 2000, 67:788-792.

5. Stamm S, Ben-Ari S, Rafalska I, Tang Y, Zhang Z, Toiber D, Thanara TA, Soreq H: Function of alternative splicing. Gene 2005, 344: $1-20$.

6. Yura K, Shionyu M, Hagino K, Hijikata A, Hirashima $Y$, Nakahara $T$, Eguchi T, Shinoda K, Yamaguchi A, Takahashi K, Itoh T, Imanishi T, Gojobori T, Go M: Alternative splicing in human transcriptome: functional and structural influence on proteins. Gene 2006, 380:63-71.

7. Neverov AD, Artamonova II, Nurtdinov RN, Frishman D, Gelfand MS, Mironov AA: Alternative splicing and protein function. BMC Bioinformatics 2005, 6:266.

8. Resch A, Xing Y, Modrek B, Gorlick M, Riley R, Lee C: Assessing the impact of alternative splicing on domain interactions in the human proteome. Proteome Res 2004, 3:76-84.

9. Artamonova II, Gelfand MS: Comparative genomics and evolution of alternative splicing: The pessimists' science. Chem Rev 2007, 107:3407-3430.

10. Kan Z, Rouchka EC, Gish WR, States DJ: Gene structure prediction and alternative splicing analysis using genomically aligned ESTs. Genome Res 200I, I I:889-900. 
1I. Smith CW, Valcárcel J: Alternative pre-mRNA splicing: the logic of combinatorial control. Trends Biochem Sci 2000 , 25:38I-388

12. Waltereit $\mathrm{R}$, Weller M: The role of caspases 9 and 9-short (9S) in death ligand- and drug-induced apoptosis in human astrocytoma cells. Brain Res Mol Brain Res 2002, I 06:42-49.

13. Elton TS, Martin MM: Alternative splicing: a novel mechanism to fine-tune the expression and function of the human ATI receptor. Trends Endocrinol Metab 2003, |4:66-7I.

14. Taneri B, Snyder B, Novoradovsky A, Gaasterland T: Alternative splicing of mouse transcription factors affects their DNAbinding domain architecture and is tissue specific. Genome Biol 2004, 5:R75.

15. Tress ML, Martelli PL, Frankish A, Reeves GA, Wesselink J], Yeats C Olason PI, Albrecht M, Hegyi H, Giorgetti A, Raimondo D, Lagarde ] Laskowski RA, López G, Sadowski MI, Watson JD, Fariselli P, Rossi I, Nagy A, Kai W, Størling Z, Orsini M, Assenov Y, Blankenburg H, Huthmacher C, Ramírez F, Schlicker A, Denoeud F, Jones P, Kerrien S, Orchard S, Antonarakis SE, Reymond A, Birney E, Brunak S, Casadio R, Guigo R, Harrow J, Hermjakob $H$, Jones DT, Lengauer $T$, Orengo CA, Patthy L, Thornton JM, Tramontano A, Valencia A: The implications of alternative splicing in the ENCODE protein complement. Proc Natl Acad Sci USA 2007, I 04:5495-5500.

16. Krawczak M, Reiss J, Cooper DN: The mutational spectrum of single base-pair substitutions in mRNA splice junctions of human genes: Causes and consequences. Hum Genet 1992 90:4I-54.

17. Goren A, Kim E, Amit M, Bochner R, Lev-Maor G, Ahituv N, Ast G Alternative approach to a heavy weight problem. Genome Res 2008, I 8:214-220.

18. Cooper TA, Mattox W: The regulation of splice-site selection, and its role in human disease. Am J Hum Genet 1997, 6 I :259-266.

19. Blencowe BJ: Exonic splicing enhancers: Mechanism of action, diversity and role in human genetic diseases. Trends Biochem Sci 2000, 25:106-110

20. Fairbrother WG, Holste D, Burge CB, Sharp PA: Single nucleotide polymorphism-based validation of exonic splicing enhancers. PloS Biol 2004, 2:E268.

21. Gardina PJ, Clark TA, Shimada B, Staples MK, Yang Q, Veitch J, Schweitzer A, Awad T, Sugnet C, Dee S, Davies C, Williams A, Turpaz Y: Alternative splicing and differential gene expression in colon cancer detected by a whole genome exon array. BMC Genomics 2006, 7:325.

22. $\mathrm{Xu} \mathrm{Q}$, Lee C: Discovery of novel splice forms and functional analysis of cancer-specific alternative splicing in human expressed sequences. Nucleic Acids Res 2003, 3 I :5635-5643.

23. Sonnhammer EL, Eddy SR, Durbin R: Pfam: a comprehensive database of protein domain families based on seed alignments. Proteins 1997, 28:405-420.

24. Attwood TK, Bradley P, Flower DR, Gaulton A, Maudling N, Mitchell AL, Moulton G, Nordle A, Paine K, Taylor P, Uddin A, Zygouri C: PRINTS and its automatic supplement, prePRINTS. Nucleic Acids Res 2003, 3 I:400-402.

25. Wilming LG, Gilbert JGR, Howe K, Trevanion S, Hubbard T, Harrow JL: The vertebrate genome annotation (Vega) database. Nucleic Acids Res 2008, 36:D753-D760.

26. Thanaraj TA, Stamm S, Clark F, Riethoven JJ, Le Texier V, Muilu J: ASD: the Alternative Splicing Database. Nucleic Acids Res 2004 32:D64-D69.

27. Stamm S, Riethoven J], Le Texier V, Gopalakrishnan C, Kumanduri V, Tang Y, Barbosa-Morais NL, Thanaraj TA: ASD: a bioinformatics resource on alternative splicing. Nucleic Acids Res 2006 34:D46-D55.

28. The UniProt Consortium: The Universal Protein Resource (UniProt). Nucleic Acids Res 2007, 35:DI93-DI 97.

29. Kozak M: Compilation and analysis of sequences upstream from the translational start site in eukaryotic mRNAs. Nucleic Acids Res 1984, I 2:857-872.

30. Quevillon E, Silventoinen V, Pillai S, Harte N, Mulder N, Apweiler R Lopez R: InterProScan: protein domains identifier. Nucleic Acids Res 2005, 33:WI 16-WI20.

31. Sonnhammer EL, Eddy SR, Birney E, Bateman A, Durbin R: Pfam: multiple sequence alignments and HMM-profiles of protein domains. Nucleic Acids Res 1998, 26:320-322

32. Finn RD, Mistry J, Schuster-Böckler B, Griffiths-Jones S, Hollich V Lassmann T, Moxon S, Marshall M, Khanna A, Durbin R, Eddy SR, Son- nhammer EL, Bateman A: Pfam: clans, web tools and services. Nucleic Acids Res 2006, 34:D247-D25I

33. Altschul SF, Madden TL, Schaffer AA, Zhang J, Zhang Z, Miller W, Lipman DJ: Gapped BLAST and PSI-BLAST: a new generation of protein database search programs. Nucleic Acids Res 1997, 25:3389-3402.

34. Boutselakis H, Dimitropoulos D, Fillon J, Golovin A, Henrick K, Hussain A, lonides J, John M, Keller PA, Krissinel E, McNeil P, Naim A, Newman R, Oldfield T, Pineda J, Rachedi A, Copeland J, Sitnov A, Sobhany S, Suarez-Uruena A, Swaminathan J, Tagari M, Tate J, Tromm S, Velankar S, Vranken W: E-MSD: the European Bioinformatics Institute Macromolecular Structure Database. Nucleic Acids Res 2003, 3 I:458-462.

35. McKusick VA: Mendelian Inheritance in Man. A Catalog of Human Genes and Genetic Disorders. The online version is: Online Mendelian Inheritance in Man, OMIM (TM). McKusick-Nathans Institute of Genetic Medicine, Johns Hopkins University (Baltimore, MD) and National Center for Biotechnology Information, National Library of Medicine (Bethesda, MD) I2th edition. 1998 [http:// www.ncbi.nlm.nih.gov/omim/]. Baltimore: Johns Hopkins University Press

36. Baek D, Green P: Sequence conservation, relative isoform frequencies, and nonsense-mediated decay in evolutionarily conserved alternative splicing. Proc Natl Acad Sci USA 2005, 102:12813-12818.

37. Lewis BP, Green RE, Brenner SE: Evidence for the widespread coupling of alternative splicing and nonsense-mediated mRNA decay in humans. Proc Natl Acad Sci USA 2003 I00:189-192.

38. de la Grange P, Dutertre M, Correa M, Auboeuf D: A new advance in alternative splicing databases: from catalogue to detailed analysis of regulation of expression and function of human alternative splicing variants. BMC Bioinformatics 2007, 8: 180 .

39. Takeda J, Suzuki Y, Nakao M, Barrero RA, Koyanagi KO, Jin L, Motono C, Hata H, Isogai T, Nagai K, Otsuki T, Kuryshev V, Shionyu M, Yura K, Go M, Thierry-Mieg J, Thierry-Mieg D, Wiemann S, Nomura N, Sugano S, Gojobori T, Imanishi T: Large-scale identification and characterization of alternative splicing variants of human gene transcripts using 56419 completely sequenced and manually annotated full-length cDNAs. Nucleic Acids Research 2006, 34:3917-3928.

40. PRINTS [http://www.bioinf.manchester.ac.uk/dbbrowser/PRINTS/ printscontents.html]

41. Gene Ontology Consortium: Gene Ontology: tool for the unification of biology. Nature Genet 2000, 25:25-29.

42. Liu S, Altman RB: Large scale study of protein domain distribution in the context of alternative splicing. Nucleic Acids Research 2003, 3 I:4828-4835

43. Waltereit R, Weller M: The role of caspases 9 and 9-short (9S) in death ligand- and drug-induced apoptosis in human astrocytoma cells. Brain Res Mol Brain Res 2002, 1 06:42-49.

44. Harrow J, Denoeud F, Frankish A, Reymond A, Chen CK, Chrast J, Lagarde J, Gilbert JG, Storey R, Swarbreck D, Rossier C, Ucla C, Hubbard T, Antonarakis SE, Guigo R: GENCODE: producing a reference annotation for ENCODE. Genome Biology 2006, 7(Suppl I:S4): I-9.

45. Talavera D, Vogel C, Orozco M, Teichmann SA, de la Cruz X: The (In)dependence of Alternative Splicing and Gene Duplication. PloS Comput Biol 2007, 3:e33.

46. Heger A, Holm L: Exhaustive enumeration of protein domain families. J Mol Biol 2003, 328:749-767.

47. You KT, Li LS, Kim N-G, Kang HJ, Koh KH, Chwae Y-J, Kim KM, Kim YK, Park SM, Jang SK, Kim H: Selective translational repression of truncated proteins from frameshift mutation-derived mRNAs in tumors. PloS Biol 2007, 5:el09.

48. Neu-Yilik G, Gehring NH, Hentze MW, Kulozik AE: Nonsensemediated mRNA decay: from vacuum cleaner to Swiss army Knife. Genome Biol 2004, 5:2 18

49. Kim E, Goren A, Ast G: Insights into the connection between cancer and alternative splicing. Trends Genet 2008, 24:7-I0.

50. Buratti E, Baralle M, Baralle FE: Defective splicing, disease, and therapy: searching for master checkpoints in exon definition. Nucleic Acids Res 2006, 34:3494-35 I0.

5I. Hubbard TJ, Aken BL, Beal K, Ballester B, Caccamo M, Chen Y, Clarke L, Coates G, Cunningham F, Cutts T, Down T, Dyer SC, Fitzgerald S, Fernandez-Banet J, Graf S, Haider S, Hammond M, Herrero J, Holland 
R, Howe K, Howe K, Johnson N, Kahari A, Keefe D, Kokocinski F, Kulesha E, Lawson D, Longden I, Melsopp C, Megy K, Meidl P, Ouver$\operatorname{din}$ B, Parker A, Prlic A, Rice S, Rios D, Schuster M, Sealy I, Severin J, Slater G, Smedley D, Spudich G, Trevanion S, Vilella A, Vogel J, White $S$, Wood M, Cox T, Curwen V, Durbin R, Fernandez-Suarez XM, Flicek P, Kasprzyk A, Proctor G, Searle S, Smith J, Ureta-Vidal A, Birney E: Ensembl 2007. Nucleic Acids Res 2007, 35:D6 I0-D6I7.

52. Clark F, Thanaraj TA: Categorization and characterization of transcript-confirmed constitutively and alternatively spliced introns and exons from human. Human Molecular Genetics 2002, I I:45I-464.

53. Holste D, Huo G, Tung V, Burge CB: HOLLYWOOD: a comparative relational database of alternative splicing. Nucleic Acids Res 2006, 34:D56-D62.

54. Kim N, Alekseyenko AV, Roy M, Lee C: The ASAPII database: analysis and comparative genomics of alternative splicing in 15 animal species. Nucleic Acids Res 2007, 35:D93-D98.

55. Takeda J, Suzuki Y, Nakao M, Kuroda T, Sugano S, Gojobori T, Imanishi T: H-DBAS: alternative splicing database of completely sequenced and manually annotated full-length cDNAs based on H-Invitational. Nucleic Acids Res 2007, 35:D I04-DI09.

56. Lee Y, Lee Y, Kim B, Shin Y, Nam S, Kim P, Kim N, Chung WH, Kim J, Lee S: ECgene: an alternative splicing database update. Nucleic Acids Res 2007, 35:D99-DI03.

57. de la Grange $P$, Dutertre M, Correa M, Auboeuf $D$ : A new advance in alternative splicing databases: from catalogue to detailed analysis of regulation of expression and function of human alternative splicing variants. BMC Bioinformatics 2007, 8: 180 .

58. Foissac S, Sammeth M: ASTALAVISTA: dynamic and flexible analysis of alternative splicing events in custom gene datasets. Nucleic Acids Res 2007, 35:W297-W299.

59. Le Texier V, Riethoven JJ, Kumanduri V, Gopalakrishnan C, Lopez F, Gautheret D, Thanaraj TA: AltTrans: Transcript pattern variants annotated for both alternative splicing and alternative polyadenylation. BMC Bioinformatics 2006, 7:169.

60. Castrignanò T, D'Antonio M, Anselmo A, Carrabino D, D'Onorio De Meo A, D'Erchia AM, Licciulli F, Mangiulli M, Mignone F, Pavesi G, Picardi E, Riva A, Rizzi R, Bonizzoni P, Pesole G: ASPicDB: A database resource for alternative splicing analysis. Bioinformatics 2008, 24:1300-1304.

61. Mulder NJ, Apweiler R, Attwood TK, Bairoch A, Bateman A, Binns D, Bork P, Buillard V, Cerutti L, Copley R, Courcelle E, Das U, Daugherty L, Dibley M, Finn R, Fleischmann W, Gough J, Haft D, Hulo N, Hunter S, Kahn D, Kanapin A, Kejariwal A, Labarga A, LangendijkGenevaux PS, Lonsdale D, Lopez R, Letunic I, Madera M, Maslen J, McAnulla C, McDowall J, Mistry J, Mitchell A, Nikolskaya AN, Orchard S, Orengo C, Petryszak R, Selengut JD, Sigrist C], Thomas $\mathrm{PD}$, Valentin F, Wilson $\mathrm{D}, \mathrm{Wu} \mathrm{CH}$, Yeats $\mathrm{C}$ : New developments in the InterPro database. Nucleic Acids Res 2007, 35:D224-D228.

62. Loraine AE, Helt GA, Cline MS, Siani-Rose MA: Exploring Alternative transcript structure in the human genome using Blocks and Interpro. J Bioinform Comput Biol 2003, I:289-306.

63. Kriventseva EV, Koch I, Apweiler R, Vingron M, Bork P, Gelfand MS: Increase of functional diversity by alternative splicing. Trends Genet 2003, 19:124-128.
Publish with Bio Med Central and every scientist can read your work free of charge

"BioMed Central will be the most significant development for disseminating the results of biomedical research in our lifetime. "

Sir Paul Nurse, Cancer Research UK

Your research papers will be:

- available free of charge to the entire biomedical community

- peer reviewed and published immediately upon acceptance

- cited in PubMed and archived on PubMed Central

- yours - you keep the copyright

Submit your manuscript here:

http://www.biomedcentral.com/info/publishing_adv.asp
BioMedcentral 